Amasya Ilahiyat Dergisi - Amasya Theology Journal

ISSN 2667-7326 | e-ISSN 2667-6710

Aralık / December 2020, 15: 363-393

\title{
İmâm-1 Rabbânî'nin el-Mektûbât İsimli Eseri Bağlamında Nakşibendiyye Şeyhlerinde Bulunması Gereken Vasıflar
}

\author{
Mevlüt ÖZÇELIK \\ Dr. Öğr. Üyesi, Amasya Üniversitesi, İlahiyat Fakültesi, \\ Tasavvuf Anabilim Dalı \\ Assistant Professor, Amasya University, Faculty of Theology, \\ Department of Sufism \\ Amasya, Turkey \\ mevlut.ozcelik@amasya.edu.tr \\ orcid.org/0000-0003-1434-2135
}

\section{Makale Bilgisi / Article Information}

Makale Türü / Article Types: Araştırma Makalesi / Research Article

Geliş Tarihi / Received: 14 Ağustos / August 2020

Kabul Tarihi / Accepted: 17 Eylül / September 2020

Yayın Tarihi / Published: 30 Aralık / December 2020

Yayın Sezonu / Pub. Date Season: Aralık / December

Sayı / Issue: 15 Sayfa / Pages: 363-393

Atıf / Cite as: Özçelik, Mevlüt. “İmâm-1 Rabbânî'nin el-Mektûbâtİsimli Eseri Bağlamında Nakşibendiyye Şeyhlerinde Bulunması Gereken Vasıflar [The Qualities that should have in the Naqshbandiyya Sheikhs in the Context of Imam Rabbani's Work Titled al-Maktubat]". Amasya Ilahiyat Dergisi-Amasya Theology Journal 15 (December 2020): 363-393.

https://doi.org/10.18498/amailad.780597.

Intihal / Plagiarism: Bu makale, en az iki hakem tarafından incelendi ve intihal içermediği teyit edildi. / This article has been reviewed by at least two referees and scanned via a plagiarism software.

Copyright (C Published by Amasya Üniversitesi, İlahiyat Fakültesi / Amasya University, Faculty of Theology, Amasya, 05100 Turkey. All rights reserved. https://dergipark.org.tr/amailad. 
364 | M. ÖZÇELIK / İmâm-1 Rabbânî'nin el-Mektûbât İsimli Eseri Bağlamında Nakşibendiyye Şeyhlerinde Bulunması Gereken Vasıflar

\section{The Qualities that should have in the Naqshbandiyya Sheikhs in the Context of Imam Rabbani's Work Titled al-Maktubat}

\section{Abstract}

In this article, from the point of view of Imam Rabbani Ahmad Farouk alSarhandi, it was tried to present the qualifications required to be a sheikh, who is at the center of sufi education. The phrase "sufism is not a science of words, but a science of experience" draws attention to the importance of the sheikh in the system of sufi education. Because the sufi education is not conveyed with the information learned from the books, but through the sheikhs who actually lived this education in their soul. According to Imam Rabbani, the true sheikhs were the heirs of the Prophet (pbuh) in conveying people to the true path. But in order to be able to talk about a sound sufi education, the sheikh, who provided this education, must also bear on some qualities: the sheikh must have the scientific heritage of the Prophet (pbuh). His scientific heritage consists of the religious provisions and secrets. The sciences of provisions are the ostensible sciences that constitute the origin of shariah, while the sciences of secrets are sufistical knowledges. The sciences of religious provisions are like the root of a tree, whereas the sufistical knowledges are like the fruits of the tree. Just as it is impossible for a rootless tree to bear fruit, it is impossible for sufistical knowledges to emerge without the sciences of religious provisions. Therefore, the sheikh must master in both sciences.

Sheikh must comply the sunnah of the Prophet (pbuh). There are seven degrees of this compliance: The first degree belongs to the common Muslims who have faith and fulfill the apparent provisions of the shariah. The second degree belongs to the people of the Tariqa who follows the words and deeds of the Prophet (pbuh) in matters such as beautifying morality, refinement of the nafs and purification of the heart. The third degree belongs to the saints who follows the spiritual state and discoveries of the Prophet (pbuh). The fourth degree belongs to the scholars who have the right to be in the status of the heirs of Prophet (pbuh). This degree can be achieved by obeying the Prophet (pbuh) in the full sense and abandoning all kinds of innovation. The fifth degree belongs to the Prophets of Perseverance who follows the perfection of Prophet (pbuh). The sixth degree is to be being subject to the perfection of the Prophet (pbuh) regarding the position of "mahbubiyyah". The seventh degree is the most comprehensive degree that includes all degrees. In this degree, there is a great similarity between the followed and follower; but the follower is another person, the followed is another one. 
M. ÖZÇELIK / The Qualities that should have in the Naqshbandiyya Sheikhs in the Context of Imam Rabbani's Work Titled al-Maktubat I 365 The sheikh must be from the people of "sahw" (spiritual alertness), not from the people of "sakr" (spiritual ecstasy). This is possible by completing the process of spiritual development under the perfect sheikh. It is impossible for someone in a "sakr" situation to educate the disciples. Such people's word that contradict the apparent provisions of shariah are not respected. Also, the sheikh must know how to behave towards his disciples. The sheikh should not teach the science of sufistical instruction to anyone without doing "istikhara" and should not be proud of the multitude of his disciples nor should he seek fame; while training his disciples he should only aim at gaining Allah's approval and should not pursue any interests.

The sheikh should act with the awareness that he is an exemplary figure for her disciples; he should abandon "rukhsah" while act with azimah (determination), and he must carefully protect the boundaries of the shariah in all respects, especially in teaching the sciences of tariqa to female students.

According to Imam Rabbani, the sheikh, who has the above qualities, is the true sheikh while the sheikh, who lacks these qualities, is an imperfect sheikh. Just as the imperfect doctors jeopardize the material life of the patients who applied to him, the imperfect sheikhs also jeopardize the spritual life of the disciples who attached to them. Therefore, a disciple who entered the sufi path, must pay attention to whether the sheikh to whom will has the qualities of the perfect sheikh. Otherwise, it is not possible for the disciple to mature spiritually.

Keywords: Sufism, Imam Rabbani, al-Maktubat, Shaykh, Disciple.

\section{İmâm-1 Rabbânî'nin el-Mektûbât İsimli Eseri Bağlamında Nakşibendiyye Şeyhlerinde Bulunması Gereken Vasıflar}

Öz

Bu makalede İmâm-ı Rabbânî Ahmed Fâruk es-Serhendî'nin bakış açısıyla tasavvufî eğitimin merkezinde bulunan şeyhin taşıması gereken vasıflar ortaya konulmaya çalışılacaktır. "Tasavvuf, kâl ilmi değil hâl ilmidir." sözü, tasavvufî eğitim sisteminde şeyhin önemine dikkat çekmektedir. Zira tasavvufî terbiye, kitaplardan öğrenilen bilgilerle değil, bu terbiyeyi nefsinde tatbik etmiş olan icazetli şeyhler vâsıtasıyla aktarılmaktadır. İmam-ı Rabbanî' ye göre hakîkî şeyhler, insanları irşât etme konusunda Resûlullah' in (s.a.v.) vârisleridir. Ancak sahih bir tasavvufî eğitimden bahsedebilmek için bu eğitimi verecek olan şeyhin, bazı vasıfları üzerinde taşıması da gerekmektedir.

Şeyh, öncelikle Resûlüllâh'ın (s.a.v.) ilmî mirasına sahip olmalıdır. Onun ilmî mirası, "ahkâm" ve "esrâr" ilimlerinden oluşur. Ahkâm ilimleri, şerîatın aslını 
366 | M. ÖZÇELIK / İmâm-1 Rabbânî'nin el-Mektûbât İsimli Eseri Bağlamında Nakşibendiyye Şeyhlerinde Bulunması Gereken Vasıflar

oluşturan zâhirî ilimler, esrâr ilimleri ise tasavvufî mârifetlerdir. Ahkâm ilimleri ağacın kökü, tasavvufî marifetler ise o ağacın meyveleri gibidir. Köksüz bir ağacın meyve vermesi nasıl imkânsız ise ahkâm ilimleri olmadan tasavvufî mârifetlerin ortaya çıkması da imkânsızdır. O halde tasavvufî terbiye ile meşgul olan şeyhin, her iki ilme de hâkim olması gerekmektedir.

Şeyh, Resûlüllâh'in (s.a.v.) sünnetine harfiyen mutabakat etmelidir. Bu mutabakatın yedi derecesi vardır. Birinci derece, îmân edip şerîatın zâhirî hükümlerini yerine getirmekten ibaret olup avam Müslümanlara aittir. İkinci derece, ahlâkı güzelleştirme, nefis tezkiyesi ve kalp tasfiyesi gibi konularda Resûlüllâh'ın (s.a.v.) söz ve fiillerine tabi olmayı ifade eder. Bu derece, kendisine tâbi olunan bir şeyhin gözetiminde bulunan tarîkat ehline mahsustur. Üçüncü derece, Resûlüllâh'ın (s.a.v.) mânevî hal ve zevklerine tabi olmaktan ibarettir ki bu, "husûsi velâyet" makamındaki velilerin derecesidir. Dördüncü derece, Resûlüllâh'in (s.a.v.) vârisi konumunda bulunan ilimde rüsûh sahibi âlimlerin derecesidir. Bu dereceye, Resûlüllâh'a (s.a.v.) tam manasıyla uyup bid'atların her türlüsünü terk etmekle erişilir. Beşinci derece, Resûlüllâh'ın (s.a.v.) kemâlâtına tabi olmaktır ki bu, Ülü'l-Azm peygamberlere ait bir derecedir. Altıncı derece, Resûlüllâh'ın (s.a.v.) "mahbûbiyyet" makamı ile ilgili kemâlâtına tabi olmaktır. Son olarak yedinci derece ise mutâbaat derecelerinin tamamını içine alan en kapsamlı derecedir. Bu derecede tâbî ile metbû arasında büyük bir benzerlik vardır; ancak yine de tâbi başka, metbû başkadır.

Şeyh, "sekr" ehlinden değil "sahv" ehlinden olmalıdır. Bu da bir şeyh-i kâmil-i mükemmil gözetiminde mânevî gelişim sürecini tamamlamakla mümkün olur. Sekr halinde bulunan birinin, müritleri terbiye etmesi imkânsızdır. Bu haldeki kimselerin, şerîatın zâhirine ters düşen sözlerine itibar edilmez. Ayrıca şeyh, müritlerine karşı nasıl davranması gerektiğini bilmelidir. Şeyh, "istihare" yapmadan kendisine her müracaat eden kişiye tarîkat talimi yapmamall; müritlerinin çokluğu ile övünüp şöhret peşinde koşmamall; müritlerini eğitirken sadece Allâh'ın rızasını kazanmayı hedefleyip hiçbir menfaat gözetmemelidir. Yine şeyh, müritler için örnek bir şahsiyet olduğu bilinciyle hareket etmeli; ruhsatları terk edip azîmetler ile amel etmeli; her hususta ve özellikle kadın müritlerine tarîkat talimi yapma konusunda şerîatın sınırlarını aşmamaya hassasiyet göstermelidir.

İmam-1 Rabbânî'ye göre yukarıda sayılan vasıfları üzerinde taşıyan şeyh, hakîkî şeyh, bu vasıflardan yoksun olan şeyh ise eksik şeyhtir. Eksik şeyh, tıbbî bilgileri eksik olan doktora benzer. Nasıl ki eksik doktor, kendisine başvuran hastanın maddi hayatını tehlikeye sokarsa eksik şeyh de kendisine intisâb eden 
M. ÖZÇELIK / The Qualities that should have in the Naqshbandiyya Sheikhs in the Context of Imam Rabbani's Work Titled al-Maktubat I 367

müridin mânevî hayatını tehlikeye sokar. O halde tasavvuf yoluna sülûk eden bir mürîd, intisâb edeceği şeyhin, hakîkî şeyhin vasıflarını taşıyıp taşımadığına dikkat etmelidir. Aksi takdirde mürîdin kemâle ermesi imkân dâhilinde değildir.

Anahtar Kelimeler: Tasavvuf, İmâm-1 Rabbânî, el-Mektûbât, Şeyh, Mürit.

\section{Giriş}

Gerek yurt içinde gerekse yurt dişında İmâm-1 Rabbânî Ahmed Fâruk es-Serhendî (ö. 1034/1624) hakkında birçok çalışma yapılmış ve bunların çoğunda onun hayatı konu edilmiştir. ${ }^{1}$ Ancak bu çalışmalarda İmâm-1 Rabbânî'nin, tasavvufî eğitimin muallimi olan "mürşid/şeyh" unsuru hakkındaki görüşleri bir başlık altında kapsamlı olarak incelenmemiştir. Bu yüzden bu makalede, gerekli görülen hususların aktarılması dışında İmâm-1 Rabbânî'nin hayatı incelenmeyecek; elMektûbât isimli eseri kısaca analiz edilip bu eser çerçevesinde onun şeyhe bakış açısı ortaya konmaya çalışılacaktır.

Sûfî kimliği ile ön plana çıan İmâm-1 Rabbânî, İslâm'ın zaafa uğradığı, sünnet-i seniyyenin unutulduğu, bid'atların² zirveye çıktığı daha da kötüsü sözde Müslüman bir padişah tarafından "Din-i İlâhî"

1 İmâm-1 Rabbânî'nin hayatı ile ilgili geniş bilgi için bk. Necdet Tosun, İmâm-ı Rabbân̂̂ Ahmed Sirhindî Hayatı, Eserleri, Tasavoufî Görüşleri (İstanbul: İnsan Yayınları, 2016), 17-32; Ethem Cebecioğlu, "İmâm-1 Rabbânî ve Mektûbâtı”, Ankara Üniversitesi İlahiyat Fakültesi Dergisi 35/1 (1996), 194-201; Hamit Algar, "İmâm-1 Rabbânî", Türkiye Diyanet Vakfı İslâm Ansiklopedisi (İstanbul: TDV Yayınları, 2000), 22/194-199; Ebü'1-Hasan enNedvî, İslam Önderleri Tarihi, çev. Yusuf Karaca (İstanbul: Kayıhan Yayınları, 1992),

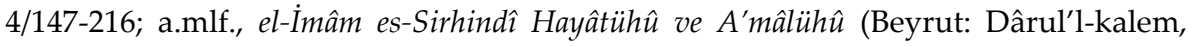
1414/1994), 113-117; a.mlf., ed-Da'vetü'l-İslâmiyye fi'l-Hind ve Tatavvurâtühâ (Lucknow: el-Mecmeu'l-İslâmî el-İlmî, 1406-1986), 12-21; Mes'ûd en-Nedvî, Târihu'd-Da'veti'lİslâmiyye fi'l-Hind (b.y.: Dâru'l-Arabiyye, 1366/1947), 97-119; Abdülmecîd b. Muhammed el-Hânî, el-Kevâkibü'd-dürriyye ale'l-hadâikı'lverdiyye fî̀ ecillâi's-sâdâti'nNakşibendiyye, tsh. Muhammed Halid el-Harse (Dımaşk: Dâru'l-Beyrûtî, 1996), 533567; Şerîf Abdulhay b. Fahruddîn el-Hasenî, Nüzhetü'l-havâtır ve behcetü'lmesâmi've'nnevâzır (Beyrut: Dâru İbn-i Hazm, 1420/1999), 5/479-485.

2 Bid'at, sünnet-i seniyyeye muhâlif bir şekilde sonradan ortaya çıkan, sahâbe-i kirâm ve tâbiîn asrında bulunmayan ve herhangi bir şer'î bir delile dayanmaksızın icrâ edilen iş demektir. (bk. Seyyid Şerif Cürcânî, Ta'rifât, nşr. Abdurrahman Umeyra (Beyrut: Âlemü'l-Kütüb, 1987), 68.) Daha geniş bilgi için bk. Rahmi Yaran, "Bid'at," Türkiye Diyanet Vakfı İslâm Ansiklopedisi (İstanbul: TDV Yayınları, 1992), 6/129-131. 
368 I M. ÖZÇELIK / İmâm-1 Rabbânî'nin el-Mektûbât İsimli Eseri Bağlamında Nakşibendiyye Şeyhlerinde Bulunması Gereken Vasıflar

adında yeni bir dinin ihdas edildiği çalkantılı bir dönemde ${ }^{3}$ tevhîd inancını hâkim kılma yönünde mücadele vermiş ve mücadelesinde muvaffak olmuş bir İslâm önderidir. Bu muvaffakiyet, ona "ikinci bin yılın yenileyicisi" anlamında "Müceddid-i Elf-i Sânî" ünvânını kazandırmıştır. Böylece $\mathrm{o}$, hem kendi çağındaki Müslümanların gafletten uyanmalarını sağlamış hem de gelecek asırlardaki Müslümanlar için ilhâm kaynağı olmuştur. ${ }^{4}$

İmâm-1 Rabbânî, "müceddid" kimliği ile bir taraftan İslâm'1 bir taraftan da tasavvufî düşünceyi tecdîd etmeye çalışmıştır. Onun İslâm'1 tecdîd etmesi, genel olarak sünnet-i seniyyeyi ihyâ edip bid'atları ortadan kaldırmak sûretiyle İslâm'ı, ehl-i sünnet ${ }^{5}$ itikadı çerçevesinde aslî hüviyetine kavuşturmak şeklinde gerçekleşmiştir. Tasavvufî yöndeki tecdîd faaliyeti ise daha çok Nakşibendiyye tarîkatı ile ilgilidir. Zira ondan önceki Nakşibendiyye şeyhlerinden bazıları, "vahdet-i vücûd" anlayışını benimsemiş, bu düşünceyi temsil eden eserleri mütalaa edip onlara şerhler yazmış ve zamanla tarîkat içinde vahdet-i vücûd düşüncesi benimsenir hale gelmiştir. ${ }^{6}$ İmâm-1 Rabbânî de gençlik yıllarında iken babası vâsıtasıyla bu düşünceyi talim etmiş ancak seyrüsülûkünü tamamladıktan sonra bu düşünceyi terk etmiş; ${ }^{7}$ irşâd makamina geçtikten sonra da vahdet-i vücûd düşüncesinin, şerîatın zâhirî ile uyuşmayan yönlerini tespit edip onları yeniden yorumlamaya; hatalı yönlerini düzeltip eksik yönlerini telafi etmeye ve zâhir-bâtın dengesini kurmaya çalışmıştır. Bu yorumlamalar, "vahdet-i şühûd" adında yeni bir düşüncenin ortaya çıkmasını sağlamıştır. Böylece bir

3 Hint coğrafyasında tevhîd inancını tehdit eden unsurlar hakkında geniş bilgi için bk. İbrahim Ethem Bilgin, Devrimci Sûfi Hareketleri ve İmam-ı Rabbân̂̂ (İstanbul: Bayrak Yayımc1lık, 1989), 38-55.

4 Tosun, İmâm-ı Rabbân̂̂ Ahmed Sirhindî, 144-147; Annemarie Schimmel, İslam'ın Mistik Boyutları, çev. Ergun Kocabıyık (İstanbul: Kabalcı Yayınevi, 2004), 384-385; Cevdet Kılıç, "Günümüz Tasavvuf Tartışmalarına İmâm-1 Rabbânî'den Çözümler", Akademiar Dergisi 2 (Haziran 2017), 58.

5 “Ehl-i Sünnet" tabirinin geniş yorumu ve İmâm-1 Rabbânî'nin Ehl-i Sünnet'e bakış açısı ile ilgili geniş bilgi için bk. Mustafa Özgen, İmâm-ı Rabbân̂̂'de Ehl-i Sünnet Kimliğ i (Konya: Palet Yayınları, 2013), 81-94.

6 Bu konuda geniş bilgi için bk. Abdullah Kartal, “İmâm-1 Rabbânî’nin Vahdet-i Vücûd Eleştirisi ve Tarihsel Arka Planı", Uludă̆ Üniversitesi İlahiyat Fakültesi Dergisi 14/2 (Haziran 2005), 71.

7 Bk. Serhendî, el-Mektûbât, 160. Mektup, 1/207-211. 
M. ÖZÇELIK / The Qualities that should have in the Naqshbandiyya Sheikhs in the Context of Imam Rabbani's Work Titled al-Maktubat I 369

taraftan Nakşibendiyye tarîkatı içinden "Müceddidiyye" adında yeni bir şube ortaya çıkarken bir taraftan da tasavvuf ilmi, birçok farklı yorum ve 1stılaha kavuşarak zenginleşmiştir. ${ }^{8}$ Ancak şunu ifade etmek gerekir ki ortaya çıan "vahdet-i şühûd" düşüncesi, "vahdet-i vücûd" düşüncesinin bütün Nakşibendiyye şubeleri nezdinde itibardan düşmesine sebep olmuş değildir. Zira gerek İmâm-1 Rabbânî döneminde gerekse ondan sonraki dönemlerde Nakşibendiyye tarîkatına mensup birçok mutasavvıf, vahdet-i vücûd düşüncesi ile ilgilenmiş; hatta bazıları bu konuda eser telif etmiştir. ${ }^{9}$

İmâm-1 Rabbânî, ayrıca bazı şeyhler tarafından sonradan benimsenen ve Nakşibendiyye tarikatının prensipleri ile bağdaşmayan raks, semâ ve zikr-i cehrî gibi uygulamaları kaldırarak tarikatı, aslî hüviyetine kavuşturmuştur. O, birçok mektubunda Nakşibendiyye yolunda ihdâs edilen şeylerin, kemâlât alameti değil cehalet göstergesi olduğunu, hakîkî kemâlâta nâil olmak için bu yolun prensiplerine sımsıkı bağlı kalmak gerektiğini ifade etmiştir. Ona göre Nakşibendiyye tarikatına mensup olan son devir sûfîlerden bazılarının, tarîkatı mükemmelleştirme adına birtakım şeyler ihdâs etmeleri, şer'î hükümleri bilmemekten ve Resûlullah'in (s.a.v.) sünnetine tabi olmamaktan kaynaklanan son derece tehlikeli şeylerdir. ${ }^{10}$

\section{1. İmâm-1 Rabbânî'nin Mektûbât İsimli Eseri}

Bilindiği üzere mektup yazmak sûretiyle İslâm'ın tebliği, Resûlüllâh (s.a.v.) tarafından tatbik edilmiş bir usuldür. Resûlüllâh'ın (s.a.v.) irşâdî vazifesine vâris olan tasavvuf büyükleri de ona tebaiyet ile bu tebliğ usulünü sürdürmüşler ve zamanla ortaya birçok "Mektûbât" türü eser çıkmıştır. Hicrî ikinci bin yılın müceddidi kabul edilen İmâm-ı Rabbânî'nin, İslâm’ı tebliğ ve Nakşibendiyye tarîkatını neşir gayesiyle

8 Tosun, İmâm-ı Rabbân̂̂ Ahmed Sirhindî, 121-124. (İmâm-1 Rabbânî́nin vahdet-i vücûd eleştirisi hakkında geni bilgi için bk. Necdet Tosun, “İmam Rabbânî’ye Göre Vahdet-i Vücud-Vahdet-i Şühûd", Tasavouf: İlmi ve Akademik Araştırmalar Dergisi (İbn Arabi Özel Sayısı-2), 23 (2009), 181-192; Kartal, “İmâm-1 Rabbânî'nin Vahdet-i Vücûd Eleştirisi ve Tarihsel Arka Planı", 63-70.)

9 Rüya Kılıç, "Nakşibendi Geleneğinde İbnü'l-Arabi: Destek mi Muhalefet mi?", Hacettepe Üniversitesi Türkiyat Araştırmaları (HÜTAD) 6 (Haziran 2007), 45-60.

10 İmâm-1 Rabbânî Ahmed Fâruk es-Serhendî, el-Mektûbât (İstanbul: Fazilet Neşriyat, 2017), 131. Mektup, 1/186-187. (Ayrıca bk. Serhendî, el-Mektûbât, 266. Mektup, 1/416417.) 
370 I M. ÖZÇELIK / İmâm-1 Rabbânî'nin el-Mektûbât İsimli Eseri Bağlamında Nakşibendiyye Şeyhlerinde Bulunması Gereken Vasıflar

kaleme aldığı mektuplardan derlenen Mektûbât da bu tür eserlerin en meşhurlarındandır. ${ }^{11}$

Mektûbât, 536 mektubu ihtiva eden üç ciltlik bir eserdir. 313 mektuptan oluşan birinci cilt, Yâr Muhammed Cedîd Bedahşî Tâlekânî tarafından 1025/1616 yılında; 99 mektuptan oluşan ikinci cilt, Abdülhay Hisârî tarafından 1028/1619 yılında; 114 mektuptan oluşan üçüncü cilt ise Muhammed Hâşim Kışmî Burhanpûrî tarafından 1031/1622 yılında derlenmiştir. Daha sonra yazılan 10 mektup ise müstakil bir cilt olmayacağ1 için üçüncü cilde ilave edilmiştir. Bu derlemelerin tamamı, müellifin hayatta olduğu zamanda gerçekleşmiştir. ${ }^{12}$

Mektûbât, sadece tasavvufî konulardan bahseden basit bir mektuplar mecmuası değil, çok yönlü ve kapsamlı bir külliyattır. Zira eser, unutulmaya yüz tutmuş olan İslâm'ın yeniden hâkim kılınması gayesi ile yaşamış olan bir "müceddid"in tevhîd mücadelesinin ürünüdür. Bu yüzden eserdeki mektupların çoğunda itikâdî ve fıkhî konular ele alınmıştır. Bu yönüyle Mektûbât, kısmen kelâmî ve fikhî bir eser olarak değerlendirilebilir. ${ }^{13}$ Müellif, bazı mektuplarında kendi mânevî tekâmül sürecinden ve şeyhleri ile arasındaki mânevî münasebetlerden bahsetmiştir. ${ }^{14} \mathrm{Bu}$ yönüyle Mektûbât, otobiyografik bir eser olarak karşımıza çıkar. ${ }^{15}$ Yine müellif, bazı mektuplarında yaşadığ 1 dönem içinde meydana gelen birtakım tarihî hâdiselerden, Hinduizm başta olmak üzere farklı inanç sistemlerine ait bazı inanç ve adetlerden bahsetmiş ${ }^{16}$ ve bu konuda Müslümanları uyarmıştır. Bu yüzden eseri, tarihî bir vesîka olarak değerlendirmek mümkündür. ${ }^{17}$ Ancak her şeyden öte Mektûbât, tasavvufî bir eserdir. Bu yüzden konularının çoğu, tasavvufî meselelerden ve Nakşibendiyye Tarîkatı'nın esaslarından

11 Cebecioğlu, "Mektûbât", 449; Algar, "Mektûbât", 11.

12 Ethem Cebecioğlu, "Mektûbât", Tasavvuf Klasikleri, ed. Ethem Cebecioğlu (İstanbul: Erkam Matbaacılık, 2010), 457; a.mlf., "İmâm-ı Rabbânî ve Mektûbâtı", 221; Tosun, İmâm-ı Rabbânî Ahmed Sirhindî, 36; Algar, "Mektûbât", 12.

13 Örnek için bk. el-Mektûbât, 1. Cilt 91, 94, 96, 111 ve 124 numaralı mektuplar; 2. Cilt 2, 5, 8, 20 ve 55 numaralı mektuplar; 3. Cilt 9, 12, 17 ve 19 numaralı mektuplar.

14 Cebecioğlu, "İmâm-ı Rabbânî ve Mektûbâtı”, 199; Tosun, İmâm-ı Rabbânî Ahmed Sirhindî, 36; Algar, "Mektûbât", 12

15 Örnek için bk. el-Mektûbât, 1. Cilt 31. Mektup.

16 Örnek için bk. el-Mektûbât, 2. Cilt, 92. Mektup; el-Mektûbât, 3. Cilt, 41. Mektup.

17 Cebecioğlu, "İmâm-1 Rabbânî ve Mektûbâtı”, 221; Tosun, İmâm-ı Rabbân̂̂ Ahmed Sirhindî, 37. 
M. ÖZÇELIK / The Qualities that should have in the Naqshbandiyya Sheikhs in the Context of Imam Rabbani's Work Titled al-Maktubat I 371

oluşur. Tasavvufî meselelerin incelendiği mektuplarda sadece tasavvufî konular anlatılmaz; onların çoğunda muhâtabın durumuna göre az ya da çok itikâdî ve fıkhî meselelere temas edilir; tarîkatın şerîattan sonra geldiği, tasavvufun şerîata tam manasıyla mutabık olması gerektiği, ${ }^{18}$ kurtuluşun ehl-i sünnet âlimlerinin görüşlerine sımsıkı bağlı kalmakla gerçekleşeceği, en büyük saadetin sünnet-i seniyyeyi ihyâ edip bid'atları ortadan kaldırmak olduğu gibi hususlara vurgu yapılır. ${ }^{19}$

Türünün en kapsamlı ve en meşhuru olarak kabul edilen Mektûbât'ın en önemli özelliklerinden biri, özgün bir yapıya sahip olmasıdır. Zira eserin müellifi, özellikle tasavvufî konuları işlerken kendinden önceki sûfîlerin görüşlerini sıralamak yerine daha çok kendi tasavvufî tecrübe, keşif ve hallerini ortaya koyar. ${ }^{20}$

Mektûbât, sıradan bir müritten şeyhülislâma, rütbesiz bir askerden en üst düzeydeki komutana; kabile reisinden valiye; hatta devlet başkanına kadar otuz dokuz farklı bölgeden geniş bir muhatap kitlesine hitap eder. ${ }^{21} \mathrm{Bu}$ yüzden mektupların konusu, muhatapların durumlarına göre farklılık arz eder:

Tarîkat mensuplarına yazılan mektuplarda daha çok tasavvufî konulardan bahsedilir ve bu konular, Nakşibendiyye tarîkatına mutâbık bir şekilde anlatılır. Bu tür mektuplarda tarîkat mensupları, Nakşibendiyye yolunda bulunmayan düşünce ve uygulamalara meyletmemeleri konusunda uyarılır; onlardan Nakşibendiyye yolunun büyüklerine muhabbet edip bu yolun prensiplerine sımsıkı bağlı kalmaları istenir. ${ }^{22}$

İlmiye sınıfına ve manevî otorite sahiplerine yazılan mektuplarda itikâdî ve fikhî konularla birlikte tasavvufî konulara da yer verilir; muhataplara sünnet-i seniyyeyi revaçta tutup bid'atlarla

18 Örnek için bk. el-Mektûbât, 1. Cilt 13, 25, 36, 41 ve 47 numaralı mektuplar; 2. Cilt 25, 44, 54 ve 82 numaralı mektuplar; 3. Cilt 13, 17, 54 ve 69 numaralı mektuplar.

19 Örnek için bk. el-Mektûbât, 1. Cilt 37, 41, 44 ve 48 numaralı mektuplar; 2. Cilt 19, 23, 36 ve 45 numaralı mektuplar.

20 Tosun, İmâm-ı Rabbânî Ahmed Sirhindî, 36-37, 40; Hamit Algar, "Mektûbât", Türkiye Diyanet Vakfı İslâm Ansiklopedisi (Ankara: TDV Yayınları, 2004), 29/11-12.

21 Ethem Cebecioğlu, "İmâm-1 Rabbânî ve Mektûbâtı" isimli makalesinde Mektubât'1 tahlil edip eserdeki mektupların gönderildikleri zümre, bölge ve kişilerin tasnifini vermiştir. Geniş bilgi için bk. Cebecioğlu, "İmâm-1 Rabbânî ve Mektûbâtı", 222-240.

22 Örnek için bk. el-Mektûbât, 1. Cilt, 40-42 numaralı mektuplar. 
372 I M. ÖZÇELIK / İmâm-1 Rabbânî'nin el-Mektûbât İsimli Eseri Bağlamında Nakşibendiyye Şeyhlerinde Bulunması Gereken Vasıflar

mücadele etmeleri yönünde tavsiyeler yapilır. ${ }^{23}$ İdareci statüsündeki kişilere yazılan mektuplarda ise daha çok itikâdî konulara değinilir ve muhataplar, bir taraftan İslâm'ı güçlendirip dînî hükümleri icrâ etmeye teşvik edilirken bir taraftan da gayr-i İslâmî düşünce ve uygulamalara karşı ikaz edilir. ${ }^{24}$

Mektubât, İmâm-1 Rabbânî́nin olgunluk çağının ve yirmi altı yıllık (1008-1034 yılları arası) irşâdî faaliyetlerinin ürünüdür. ${ }^{25} \mathrm{Bu}$ yüzden eser, onun üzerinde karar kılmış olduğu tasavvufî görüşlerini yansıtır. Örneğin o, çocukluk yıllarında babasından "vahdet-i vücûd" düşüncesini öğrenip benimsemiş olmasına rağmen seyrüsülûkünü tamamladıktan sonra bu düşüncenin, geçilmesi gereken bir makâm, "vahdet-i şühûd"un ise ondan daha yüksek bir makam olduğu kanaatine varmış ve bu düşünceye saplanılıp kalınmaması konusunda uyarılarda bulunmuştur. ${ }^{26}$ Ayrıca eser, hacim ve konu itibariyle İmâm-1 Rabbânî'nin en kapsamlı eseri olup onun tasavvufî düşüncesini en doğru şekilde yansıtmaktadır. ${ }^{27}$ Çalışmamızın Mektûbât ile sinırlandırılması da işte bu yüzdendir.

Hulasa olarak söylemek gerekirse; Mektûbât, başta Hindistan olmak üzere birçok bölgeyi tesir altında bırakmış ve bu bölgelerde unutulmaya yüz tutmuş olan İslâm'ın yeniden ihyâ edilmesinde büyük rol oynamıştır. Oynadığı bu rolün tabîi neticesi olarak Mektûbât, yazıldığı dönemden günümüze kadar ilgiyle takip edilmiş, defalarca basılmış, Farsça aslından farklı dillere tercüme edilmiş, birçok akademik çalışmaya konu olmuş ve hâlen de konu olmaya devam etmektedir. ${ }^{28}$

23 Örnek için bk. el-Mektûbât, 1. Cilt, 43-54 numaralı mektuplar.

24 Tosun, İmâm-ı Rabbânî Ahmed Sirhindî, 37. (Örnek için bk. el-Mektûbât, 1. Cilt 53 ve 65 numaralı mektuplar.)

25 Muhammed Halîm Şarkpûrî, Müceddi-i Elf-i Sânî İmâm Rabbân̂̂, çev. Ali Genceli (Konya: İslâmi Neşriyat Yayınları, 1978), 94-95; Cebecioğlu, “İmâm-1 Rabbânî ve Mektûbâtı", 220-221.

26 Bk. Serhendî, el-Mektûbât, 160. Mektup, 1/207-211. (Ayrıca bk. el-Mektûbât, 1. Cilt 31. Mektup.)

27 Hânî, el-Kevâkib, 567.

28 Cebecioğlu, "Mektûbât", 464. Mektûbât'ın baskıları ve hakkında yapılan çalışmalar hakkında geniş bilgi için bk. Tosun, İmâm-ı Rabbânî Ahmed Sirhind̂̀, 37-40; Cebecioğlu, “Mektûbât", 457-458; a.mlf., "İmâm-1 Rabbani ve Mektubâtı", 221-222. 
M. ÖZÇELIK / The Qualities that should have in the Naqshbandiyya Sheikhs in the Context of Imam Rabbani's Work Titled al-Maktubat I 373

\section{2. Şeyh-i Kâmil-i Mükemmil'in Taşıması Gereken Vasıflar}

Tasavvufî eğitim sisteminin en önemli unsurunu hiç şüphesiz "şeyh/mürşid" teşkil eder. Bir ilmin, gerçek manada tahsili, o ilmin üstadı vâsıtasıyla olduğundan hareketle tasavvufî ilim ve terbiyenin, gerçek hüviyetiyle ancak hakîkî şeyhler vâsıtasıyla tahsîl edilebileceğini rahatlıkla söyleyebiliriz. Tasavvufun kitâbî bir ilim olmadığı, onun kâl ilmi değil hâl ilmi olduğu yönündeki ifadeler, aslında "şeyh/mürşid" unsurunun önemine dikkat çekmektedir. Bundan dolayıdır ki "tasavvuf" veya "tarîkat" denince akla ilk gelen kavramlar arasında "şeyh" ve "mürşid" kavramları bulunur. Bu iki kavram, birbirlerinin yerine kullanılabilmektedir. İleriki satırlarda da görüleceği üzere İmâm-1 Rabbânî, "mürşid" kavramı yerine daha çok "şeyh" kavramını kullanır ve hakîkî şeyhi "şeyh-i kâmil" veya "şeyh-i kâmil-i mükemmil" olarak nitelendirir. Şeyh-i kâmil-i mükemmil, hem kendi kemâle ermişs, hem de başkalarını kemâle erdiren şeyh demektir. ${ }^{29}$

Şeyh, şerîat, tarîkat ve hakîkat konusunda yüksek dereceye ulaşmış olan zâta denir. Böyle kimseler, "Rabbânî âlim, rehber bir eğitimci ve doğruluk yoluna irşat eden ve efendilerin yoluna ulaşmak için kendisinden yardım isteyene yardım edebilen bir mürşit sayılır." Onun irşâdı, Cenâb-1 Hakk'ın kendisine ihsân etmiş olduğu rabbânîledünnî ilim ve mânevî-ruhânî tıp sayesinde olur. ${ }^{30}$

İmâm-1 Rabbânî'ye göre hakîkî mürşid/şeyh, kendisinden Cenâb1 Hakk'a vuslat yolu öğrenilen ve bu yolda müritlerine yardım eden zâttır. Yoksa insanlar arasında yaygın olan kanaate göre külah ve hırka giymek, şeyhlik şeceresinde yer almak ve benzeri şeyler, hakîkî mürşidin alametlerinden değildir; bunlar sadece görünüşte mürşitlik alametleri arasında sayılabilir. Bununla beraber şayet hırka, şeyh-i kâmil-i mükemmilden alınmış ve ihlas ile kullanılıyor ise bunun da birtakım mânevî semereleri olur. ${ }^{31}$

Tasavvuf erbabına göre şeyh olmadan mürîdin kendi kendine mânevî gelişim kaydetmesi imkânsızdır. Şeyhin, Resûlullah'ın (s.a.v.) vârisi olması düşüncesinden hareketle müritlerin şeyhe tabi olmaları,

29 Süleyman Uludağ, Tasavouf Terimleri Sözlüğ̈̈̈ (İstanbul: Kabalcı Yayınları, 2005), "Şeyh", 334.

30 Abdürrezzak Kâşânî, Tasavvuf Sözlü̆̆̈̈ Letâifü'l-a 'lâm fî işârâti ehli'l-ilhâm, çev. Ekrem Demirli (İstanbul: İz Yayıncılık, 2004), “eş-Şeyh”, 319.

31 Serhendî, el-Mektûbât, 190. Mektup, 1/242. 
374 I M. ÖZÇELIK / İmâm-1 Rabbânî'nin el-Mektûbât İsimli Eseri Bağlamında Nakşibendiyye Şeyhlerinde Bulunması Gereken Vasıflar

Sahabe-i Kirâm'ın Resûlullah'a (s.a.v.) tabi olmaları gibi değerlendirilmiş; 32 kendi kendine nefsini terbiye etmeye çalışan mürîd, nehir kenarında yardımcısız yürüyen bir köre ${ }^{33}$ veya dağ başında kendiliğinden biten bakımsız bir ağaca benzetilmiştir. ${ }^{34}$ Bütün bunlar, tasavvufî eğitim sisteminde şeyhin önemini ortaya koymaktadır. Ancak müritlerinin mânevî gelişimlerini sağlayacak olan şeyhin, birtakım niteliklere sahip olup bazı şartlara riayet etmesi gerekmektedir. İşte buradan itibaren İmâm-1 Rabbânî'nin Mektûbât isimli eseri bağlamında şeyhte bulunması gereken belli başlı vasıfları maddeler halinde vermek istiyoruz.

\section{1. Şeyh, Resûlullah'ın (s.a.v.) irşâdî vazifesine vâris olan} "şeyh-i kâmil-i mükemmil" olmalıdır.

İnsanların irşâdı ile alakadar olacak şeyhin, öncelikle Resûlullah'in (s.a.v.) irşâdî vazifesine sahip olan şeyh-i kâmil-i mükemmil olması gerekmektedir. Böyle şeyhler, bâtınî hastalıkların tedavi yollarını bilen mânevî doktorlardır. Eksik şeyhler ise azıcık mânevî ilerlemeyi "kemâl" zanneden ve bu yüzden kendilerine intisâb eden müritlerin mânevî kemâlâtını gerçekleştirmek yerine onların kabiliyetlerini körelten kimselerdir. ${ }^{35}$

İmâm-1 Rabbânî'ye göre Resûlüllâh'in (s.a.v.) irşâdî mirasına sahip olmak, onun ilmî mirasına da sahip olmayı gerekli kılar. O, bir mektubunda "Şüphesiz ki âlimler, peygamberlerin vârisleridir." ${ }^{36}$ meâlindeki hadîs-i şerîfi tefsir sadedinde Resûlullah'ın (s.a.v.) miras biraktı̆ğ1 ilimleri, "ahkâm ilimleri" ve "esrâr ilimleri" olmak üzere iki kısma ayırır. Ona göre bir âlimin, Resûlullah'ın (s.a.v.) hakîkî varisi olabilmesi için her iki ilimden de nasibi olması lazımdır. Çünkü vâris olan kimse, miras bırakan kimsenin her türlü malından pay alır. $O$ halde Resûlullah'ın (s.a.v.) hakîkî varisleri, ondan gelen her iki ilimden de payı

32 Şehâbüddîn Ebû Hafs Ömer b. Muhammed Sühreverdî, Âvârifü'l-maârif (Beyrut: Dâru'l-Kütübü'l-İlmiyye, 1999), 235.

33 Ebû Hâmid Muhammed Gazâlî, İhyâü ulûmi'd-dîn, thk. Ali Muhammed Mustafa Saîd el-Mehâsinî (Dımaşk: Dâru'l-Feyhâ, 1431/2010), 3/647.

34 Abdülkerîm Kuşeyrî, er-Risâletü'l-Kuşeyriyye, tsh. Hânî el-Hâc (Kâhire: el-Mektebet'tTevfîkıyye, ts.), 572 .

35 Serhendî, el-Mektûbât, 230. Mektup, 1/309.

36 Muhammed Abdu'r-Raûf el-Münâvî, Feydu'l-kadîr (Misır: el-Mektebetü'tTicâriyyeti'l-Kübrâ, 1356), 4/384. 
M. ÖZÇELIK / The Qualities that should have in the Naqshbandiyya Sheikhs in the Context of Imam Rabbani's Work Titled al-Maktubat I 375

olan kimselerdir. Bu da onların Resûlullah (s.a.v.) ile aralarındaki (mânevî) yakınlıktan kaynaklanmaktadır. ${ }^{37}$

İmâm-1 Rabbânî'ye göre (dînî) ilim ve amellerin tamamı, şerîattan istifâde edilerek elde edilmiştir. İlim ve amelin rûhu mesabesindeki "ihlâs"ın tam manada tahakkuk etmesi ise sûfiyye yoluna girmekle mümkündür. Bir sâlik, "seyr ilellâh" mesafesini kat edip "seyr fillâh" makâmına varmadığı müddetçe hakîkî manada ihlâsa erişemez ve ihlâs ehlinin kemâlâtından mahrum kalır. Her ne kadar avam halk için ihlâs, bazı amellerde çalışıp çabalayarak zorla elde edilebilse de bütün söz, fiil, harekât ve sekenâtın zorlanmadan ortaya çıkması şeklinde ortaya konan ihlâsın elde edilmesi son derece zor bir hadisedir. İmâm-1 Rabbânî'ye göre bu vasiftaki ihlâs, âfâkî ve enfüsî bütün ilâhlardan geçmekle gerçekleşir. Bu da fenâ ve bekâ makamlarını geçip husûsî velâyet makamına ulaşmakla mümkündür. Avâmın zorlanarak ortaya koyduğu ihlâs, devamlılık arz etmez; bu yüzden onların, her zaman niyetlerini yenilemeleri gerekir. Ancak "hakke'l-yakîn" derecesine vâsıl olmuş evliyâullâh, "fenâ" makâmına erip hiçbir şeyi, kendi nefisleri için yapmadıkları için onların her zaman niyetlerini tashih etmelerine gerek yoktur. Çünkü zaten niyetleri bozulmamıştır. İmâm-1 Rabbânî'ye göre bu derece ihlâsa sahip olan kimselere "muhlas", yani "ihlâsa erdirilmiş kimse" denir ki bu rütbe, Allah'ın, dilediği kimseye nasip ettiği bir fazilettir. Zorlanarak ortaya çıkan ve devamlılık arz etmeyen bir ihlasa sahip olan kimseye ise "muhlis" denir. Tasavvuf yolunda seyrüsülûk yapmanın ana gayesi, işte bu "muhlas" derecesine çıkabilmektir. Bu dereceye çıkan kimseler, kelâm ilminde istidlâlî olarak elde edilen bilgileri keşfî olarak elde etmeye başlarlar ki bu, tasavvuf yolunda elde edilen en büyük faydalardan biridir. Bu dereceye çıkan kişiler, amellerini yaparken "seyr" makamlarının adabına göre hareket edip nefis ve şeytandan kaynaklanan tembellikten kurtulmuş olurlar. ${ }^{38}$

İmâm-1 Rabbânî, başka bir mektubunda Resûlullah'ın (s.a.v.) ilmî mirasını, "sûrî" ve "manevî" olmak üzere iki kısma ayırır. Sûrî miras, "âlem-i halk" ile mânevî miras ise "âlem-i emr" ile alakalıdır. Âlem-i emr, îmân ve mârifetin karargâhı, rüşd ve hidâyetin mahallidir. Ona göre sûrî mirâs nimetine şükür, mânevî miras ile süslenmekle mümkündür. Bu da bütün emir ve yasaklarına riayet etmek sûretiyle

37 Serhendî, el-Mektûbât, 268. Mektup, 1/419.

38 Serhendî, el-Mektûbât, 59. Mektup, 1/106-107. 
376 I M. ÖZÇELIK / İmâm-1 Rabbânî'nin el-Mektûbât İsimli Eseri Bağlamında Nakşibendiyye Şeyhlerinde Bulunması Gereken Vasıflar

Resûlullah'ın (s.a.v.) sünnetine tam manada ittibâ etmekle gerçekleşir. Bu mutâbaat, Resûlullah'a (s.a.v.) olan muhabbetin bir yansımasıdır. Kemâl derecesindeki muhabbetin alâmeti ise Resûlullah'ın (s.a.v.) düşmanlarına buğzetmek ve onun getirmiş olduğu şerîata muhâlif olan kimselere açıkça düşmanlık yapmaktır. ${ }^{39}$

İmâm-1 Rabbânî'ye göre şerîatın, biri "sûret" diğeri "hakîkat" olmak üzere iki yönü vardır. Şerîatın sûreti, Allah'a, O'nun rasûlüne, Resûlullah'ın (s.a.v.) Allah Teâlâ katından getirmiş olduğu her şeye îmân ettikten sonra şer'î hükümleri yerine getirmektir. Nefsin münâzaa, reddiye, isyan ve inkârlarına rağmen ortaya konan îmân, îmânın sûretini teşkil eder. Âdâb ve erkânına göre eda edilen namaz, oruç ve diğer ahkâm-ı şer'iyye de tıpkı bunun gibi şerîatın sûret tarafını temsil eder. Şerîatın sûret kısmını yerine getiren Müslümanlar cennete girmeyi hak eder; ancak onların gireceği cennet "sûrî cennet" olacaktır. Çünkü cennetin de sûret ve hakîkat tarafı vardır. Tıpkı bunun gibi velâyet makamının da bir sûreti bir de hakîkati vardır. Şerîatın sûretini tam manasıyla edâ eden kimseler, herkese şâmil olan "umûmî velâyet"e erişirler. Allah Teâlâ'nın, îmân edenlerin velîsi/dostu olduğunu bildiren âyet-i kerime, ${ }^{40}$ bu tür velâyete işaret etmektedir. Bundan başka bir de "husûsî velâyet" vardır ki bu, tarîkata sülûk edip nefsini, tedricen "emmâre" makamından "mutmainne" makamına çıkaranlar için söz konusudur. Ancak bu velâyete ulaşmanın yolu da şerîatın hükümlerine sımsıkı sarılmaktan ve zikr-i ilâhî ile meşgul olmaktan geçmektedir. "Hâsılı, şerîatın bir sûret bir de hakîkati olmalıdır. Velâyet ve nübüvvete dair bütün kemâlâtın anaları, şer'î hükümlerdir. Velâyet makâmının kemâlâtı, şerîatın sûretinin neticeleri, nübüvvet makâmının kemâlâtı ise şerîatın hakîkatinin semereleridir." ${ }^{41}$

İmâm-1 Rabbânî, (tasavvufa dair) ilim ve mârifetlerin, şer'î hükümlerin arkasındaki başka şeyler olduğunu, onlarla ehlüllâhın nitelendiklerini söyler. Ona göre (tasavvufa dair) mârifetlerin tamamı, şer'î hükümlerin semere ve neticeleridir. Nasıl ki ağaç dikmekten asıl maksat, meyve elde etmek ve meyvelerin devamı da ağaçların sağlıklı

39 Serhendî, el-Mektûbât, 165. Mektup, 1/217.

40 "Allâh, îmân edenlerin dostudur; onları karanlıklardan nûra çıkarır..." (el-Bakara 2/257)

41 Serhendî, el-Mektûbât, 50. Mektup, 2/129-130. (İmâm-1 Rabbânî'nin velâyet ile ilgili görüşleri ve velâyet-nübüvvet mukayesesi için bk. Mustafa Özgen, İmâm-ı Rabbân̂ิ Ulûhiyet ve Nübüvvet Anlayışı (Konya: Tablet Yayınları, 2007), 452-460, 478-484. 
M. ÖZÇELIK / The Qualities that should have in the Naqshbandiyya Sheikhs in the Context of Imam Rabbani's Work Titled al-Maktubat I 377 şekilde devam etmesine bağlı ise mârifetlerin devam etmesi de şerîat ağacının sağlıklı bir şekilde devam etmesine bağlıdır. Ağaçların kökünü söküp de ondan meyve beklemek ne kadar ahmaklık ise şer'î hükümleri terk ederek veya onları riyâ yoluyla yaparak mârifetlerin devam etmesini beklemek de o kadar ahmaklıktır. Buna göre gerçek mârifet sahibi, aynı zamanda şerîata sımsıkı bağlanan kişidir. Şerîata bağlılık ne denli çok olursa mârifetler de o denli çok olacaktır. Bununla beraber şayet şer'î hükümlere karşı ciddiyetsiz olan birinden birtakım mârifetler zuhur etmiş ise onların, "istidrâc" türünden şeyler olduğuna inanmak gerekir. Kaldı ki bu tür şeyler, Müslümanlardan sadır olduğu gibi gayr-i müslimlerden de sadır olabilmektedir. O halde "şerîatın reddettiği her hakîkat, bir zındıklık ve ilhâddır." Bu yüzden ehlüllâhtan bazıları, kendilerine izin verilmeyen bazı nâfile ibadetleri terk etmişler; hatta uyumanın, izin verilmeyen nâfile ibadetleri yapmaktan daha faziletli olduğuna hükmetmişlerdir. ${ }^{42}$

\section{2. Şeyh, Resûlullah'ın (s.a.v.) sünnet-i seniyyesine tam bir mutâbaat içinde olmalıdır.}

İmâm-1 Rabbânî'nin tasavvuf anlayışı, sünnet-i seniyyeye tam mutâbaat üzerine bina edilmiştir. Ona göre Resûlullah'a (s.a.v.) mutâbaat, dünyevî ve uhrevî bütün mutlulukların başıdır. Bu mutâbaatın yedi derecesi vardır:

Birinci derece, İslam'ın esaslarını kalben tasdik etmiş, ancak nefisleri mutmainne seviyesine çıkmamış olan avam halkın mutâbaatıdır ki bu, (zâhiren) şer'î hükümleri yerine getirip sünnet-i seniyyeye tabi olmaktan ibarettir. Bu derece, "(umûmî) velâyet" makamı ile alakalıdır. Zâhir ulemâ, âbidler, zâhitler ve nefs-i mutmainne makamına çıkmamış bütün Müslümanlar, bu derecede bulunurlar. Bu derecedeki mutâbaat, sûrî bir mutâbaattır. Çünkü bu makamdaki kimselerin nefisleri, henüz tam manasiyla küfür ve inkârdan kurtulamamıştır. Bununla beraber bu derecedeki mutâbaat, sahibinin cehennemden kurtulup cennete gitmesine vesîle olur. ${ }^{43}$

İkinci derece, ahlakı güzelleştirme, kötü sıfatları yok etme, kalbî hastalıkları ve mânevî illetleri izâle etme gibi kalp (tasfiyesi) ile alakalı olan Resûlullah'in (s.a.v.) söz ve fiillerine tabi olma şeklinde tezahür eden mutâbaattır. Bu derece, tâbi olunan bir şeyhten tasavvuf yolunu

42 Serhendî, el-Mektûbât, 55. Mektup, 2/147-148.

43 Serhendî, el-Mektûbât, 54. Mektup, 2/136-137. 
378 I M. ÖZÇELIK / İmâm-1 Rabbânî'nin el-Mektûbât İsimli Eseri Bağlamında Nakşibendiyye Şeyhlerinde Bulunması Gereken Vasıflar

talim ederek Allah Teâlâ'ya doğru seyr vâdilerini geçen tarîkat ehline aittir. ${ }^{44}$

Üçüncü derece, Resûlullah'ın (s.a.v.) hallerine, mânevî zevklerine ve vecdlerine tabi olmak sûretiyle gösterilen mutâbaattır. Bu derece, "husûsi velâyet" makaminda bulunan velîlere mahsustur. Bu makamın sonuna ulaşan velinin nefsi, tam manasıyla mutmainne makamına çıkmış olur. Bu yüzden onun nefsi, artık inat ve isyanı bırakmış, inkârdan ikrâra, küfürden İslâm'a intikal etmiştir. Bu durumdaki kişi, gayret ettiği takdirde bir sonraki dereceye ait olan "hakîkî mutâbaat" nimetine nail olur. Bu mutâbaat ile yerine getirilen ibâdetler, hakîkî ibâdet derecesini kazanır. Şöyle ki "nefs-i emmâre" konumunda olan nefis, her ne kadar şer'î hükümleri zâhiren yerine getirse de kalben inkâr eder; ancak "mutmainne" makamına çıan nefis, artık şer'î hükümleri hoşnutlukla ve rağbet ederek yapar. Bu yüzden nefs-i mutmainne makaminda bulunan kimselerin ibadetleri "hakîkî ibâdet", bu makama çıkmayan kimselerin ibadetleri ise "sûrî ibâdet" olur. Bir ibadetin sûrî veya hakîkî oluşu, kalbin, (bedenin yaptığı ibadetleri) ikrâr edip etmemesine göre değerlendirilir. ${ }^{45}$

Dördüncü derece, ilimde rüsûha ermiş olan âlimlere ait olan mutâbaattır. Onlar, bu makama nefislerini mutmainne makamına çıkardıktan sonra erişirler. İmâm-ı Rabbânî'ye göre nefsin kemâl derecede itmi'nâna erişmesi, nübüvvet makâmının kemâlatını elde etmekten geçer. Peygamberlerin varisleri olmaları hasebiyle âlimlerin bu makamdan nasipleri vardır. Onlar, nefislerini kemâl derecede itmi'nâna eriştirme yoluyla şerîatın hakikatine vâkıf olmuşlardır. "Hakîkî mutâbaat" denen şey, işte bundan ibarettir. Nefislerini kemâl derecede itmi'nâna kavuşturamayan diğer insanlar ise bazen şerîatın sûreti ile bazen de şerîatın hakîkati ile amel ederler. İlimde rüsûha ermiş olan âlimlerin alâmeti, müteşâbih âyet-i kerime ve hadis-i şerifleri tevil edebilmek, surelerin başında bulunan hurûf-i mukattaalardaki esrardan haberdar olmak ve kapalı halde bulunan birtakım esrara vakıf olmaktır. Ancak burada kastedilen tevil, ayet-i kerimelerde geçen "Allah'ın eli" ifadesini "Allah'ın kudreti", "Allah'ın vechi" ifadesini "Allah'ın zâtı" şeklinde yorumlamaktan ibaret değildir. Çünkü bu tür teviller, zâhir ulemanın ilminden neşet etmiş yorumlardır ki bunların, esrâr ile alakası

44 Serhendî, el-Mektûbât, 54. Mektup, 2/137.

45 Serhendî, el-Mektûbât, 54. Mektup, 2/138. 
M. ÖZÇELIK / The Qualities that should have in the Naqshbandiyya Sheikhs in the Context of Imam Rabbani's Work Titled al-Maktubat I 379 yoktur. İnsanlara kapalı olan esrârın sahipleri, peygamberler (a.s.) ve onlara tam mutâbaat gösteren peygamber varisleridir. Mutâbaatın bu derecesi, nefs-i mutmainne makâmının tamamlanıp Resûlullah'a (s.a.v.) tam manada mutâbaatın sağlanması neticesinde gerçekleşir. İmâm-1 Rabbânî'ye göre bu makamı elde etmek, sünnet-i seniyyeye sımsıkı sarılmak ve bid'atın her türlüsünden ${ }^{46}$ kaçınmakla mümkündür. Aksi takdirde kişinin, bu makamın kokusunu alması bile mümkün değildir. ${ }^{47}$

Beşinci derece, Resûlullah'ın (s.a.v.) kemâlâtına tabi olmayı ifade eden mutâbaattır. Ülü’l-Azm peygamberlere (a.s.) ait olan bu derece, gâyet yüksek bir mertebe olup önceki derecelerin bununla bir alakası yoktur. Bu dereceye, ilim ve amel ile değil, sırf Cenâb-1 Hakk'ın lütfu ve ihsânıyla erişilir. Her kim, bu derece için murâd edilmiş ise o kişi, tebaiyet ve verâset yoluyla bu dereceye nâil olur. ${ }^{48}$

Altıncr derece, Resûlullah'a (s.a.v.), onun "mahbûbiyyet" makamına mahsus olan kemâlâtı konusunda ittibâ etmektir. Beşinci

46 İmâm-1 Rabbânî, bir mektubunda Resûlullah'ın (s.a.v.) peygamber olarak gönderilişinin üzerinden bin yılın geçip kıyametin bütün alamet ve şartlarının zuhur ettiğini, sünnetlerin gizlenip bid'atların üstün görülmeye başladığını, dolayısıyla sünnet-i seniyyeyi ihyâ edip bid'atları yok edecek doğan kuşu (gibi cesaretli, gözü pek) bir zâta ihtiyaç duyulduğunu söyler. Ona göre bid'atları revaçta tutmak, dinin tahrip edilmesine, bid'atçılara hürmet etmek ise İslâm'ın yıkılmasına sebep olacaktır. $\mathrm{Bu}$ yüzden Müslümanların, bütün gayretlerini, sünnetleri diriltip bid'atları yok etmeye sarf etmeleri gerekmektedir. Her ne kadar geçmiş dönemdeki âlimler, içinde bulundukları şartlara göre "bid'at-i hasene" diye bir kavram geliştirmişler se de "Her bid'at dâlâlettir ve her dalâlet cehennemdedir."46 "Her kim, bizim şu (din) işimizde onda olmayan bir şey ihdâs etmiş ise o reddolunmuştur." 46 hadîs-i şeriflerinden dolayı bid'atın hiçbir türüne müsamaha göstermemek gerekmektedir. Dinde reddolunan bir şeyin, iyisi kötüsü olmaz. İslâm'ın garip ve zayıf olduğu, bid'at zulmetlerinin zirveye ulaştığı bir dönemde kurtuluş, sünneti diriltmeye bağlıdır. Böyle bir dönemde geçmiş ulemânın "bid'at-ı hasene" ye verdikleri cevaz hükmü ile amel etmenin hiçbir faydası bulunmamaktadır. Ona göre her dönemde, o döneme ait birtakım hükümler vardır. İslâm nurunun parladığı geçmiş yıllarda, bid'at karanlıkları, aslında nûrânî olmamakla birlikte o dönemin âlimlerine nûrânî olarak görünmüş ve bu yüzden onlar, "bid'at-i hasene" diye bir tabir geliştirmişlerdir. Bid'at karanlıklarının deniz karanlıkları gibi çoğaldığı bu dönemde ise sünnet, garipliğinden ve azlığından dolayı denizdeki meşaleler gibi cılız kalmaktadır. Hal böyleyken bid'at olan fiillerle meşgul olmak, bid'atların zulmetini artırıp sünnetin nûrunu zayıflatmaktan başka işe yaramayacaktır. (Serhendî, el-Mektûbât, 23. Mektup, 2/51-52.)

47 Serhendî, el-Mektûbât, 54. Mektup, 2/138-139.

48 Serhendî, el-Mektûbât, 54. Mektup, 2/139-140. 
380 I M. ÖZÇELIK / İmâm-1 Rabbânî'nin el-Mektûbât İsimli Eseri Bağlamında Nakşibendiyye Şeyhlerinde Bulunması Gereken Vasıflar

derecedeki mânevî kemâlatın tâbi olan kişiye sirâyeti, sırf Cenab-1 Hakk'ın lütfu ve ihsanı ile olurken bu derecedeki kemâlâtın siyâyeti ise lütf-i ilâhî ve ihsân-1 ilâhînin üstünde bulunan muhabbet-i ilâhî ile olur. Bu derece, azdan da az kişilere nasip olan bir derecedir. ${ }^{49}$

Yedinci dereceye gelince; bu derece, diğer altı dereceyi de içine alan kapsamlı bir derecedir. Birinci derece dışındaki diğer beş derece, urûc (manevî yükseliş) makamları ile alâkalıdır. Yedinci derece ise hem urûc hem de nüzûl (iniş) ile alakalı bir derecedir. ${ }^{50} \mathrm{Bu}$ derece "kül", diğer altı derece ise bu küllün cüzleri gibidir. Bu derecede "tâbi" ile "metbû" arasında bir cihetten benzerlik vardır. Sanki tâbî ile metbû arasındaki "tebaiyet" ortadan kalkmış, "tâbi" ile "metbû" ayırt edilmez olmuştur. Bu yüzden "tâbi" olan zâtın, tıpki "metbû" gibi (mârifet ve ilham türünden) aldığı her şeyi, asıl kaynaktan aldığı; ikisinin de aynı pınardan su içtikleri ve aynı yastığa baş koydukları zannedilmeye başlanmıştır. Onlar, şeker ile sütün birbirinden ayırt edilmediği gibi birbirinden ayırt edilmezler. Nispet birliği bakımından onlar arasında herhangi bir farklılık yoktur. Bütün bunlara rağmen "tâbî" başka "metbû" başkadır. Zaten bu derece mutâbaat ile vasıflanan bir tâbî, kendisinin tufeylî, yani peygamberinin yörüngesinde bulunduğunu ve onun vârisi olduğunu bilir. Varlık âlemine gelen nimetlerin tamamı peygamberler (a.s.) için gelmiştir. Ümmetlerin saâdeti, peygamberlere tabi olmak suretiyle onlarla gelen nimetlerden nasipdar olmalarına bağlıdır. ${ }^{51}$

İmâm-1 Rabbânî'ye göre Resûlullah'a (s.a.v.) gerçek manada tabi olan kişinin, mutâbaatın bu yedi derecesi ile bezenmiş olması gerekir. $\mathrm{Bu}$ derecelerden bazısına sahip olup bazısından mahrum olan kişi ise

49 Serhendî, el-Mektûbât, 54. Mektup, 2/140.

50 Urûc, mürîdin, seyrüsülûk ile Cenâb-1 Hakk'a doğru mânen yükselmesi ve terakkî etmesini ifade eder. Bu, bir bakıma vuslat-1 ilâhî yolunda ilerlemektir. Nüzûl ise mânen terakkî etmiş olan zâtın, insanları irşâd etmek üzere vuslat makamından kulların seviyesine inmesi demektir. Velâyet mertebesinde bulunan velîler manevî kemâlatını tamamlamak üzere sürekli urûc halindedirler. Nübüvvet makâmında bulunan peygamberler (ve bu peygamber varisi olan zatlar) ise hem urûc hem nüzûl halindedirler. Zira peygamberler (a.s.) bir taraftan Cenâb-1 Hakk'a doğru urûc ederlerken bir taraftan da insanları irşâd etmek üzere onların seviyesine nüzûl ederler. Bk. Serhendî, el-Mektûbât, 46. Mektup, 2/120-121) "Nüzûll" ve "urûc" kavramlarının değerlendirmesi için bk. Tosun, İmâm-ı Rabbânî Ahmed Sirhindî, 64-69.

51 Serhendî, el-Mektûbât, 54. Mektup, 2/140. 
M. ÖZÇELIK / The Qualities that should have in the Naqshbandiyya Sheikhs in the Context of Imam Rabbani's Work Titled al-Maktubat I 381

sadece genel anlamda bir tâbi sayılır. Zâhir ulemâsı, mutâbaatın sadece birinci derecesi ile iktifa edip mesrur olmuşlar; ancak bunu da tam manada gerçekleştirememişlerdir. Çünkü onlar, tebaiyeti, sadece şerîatın sûretine tabi olmakla sınırlandırıp diğer tebaiyet derecelerini hesaba katmamışlardır. Daha da kötüsü onların çoğu, bu tebaiyet derecelerine ulaşmaya vesîle olan sûfiyyenin yolunu gereksiz görmüşler ve bu yüzden kendilerine tabi olacakları bir şeyh edinmemişlerdir. ${ }^{52}$

\section{3. Şeyh, sekr ehlinden değil, sahv ehlinden olmalıdır.}

Müritlerin mânevî terbiyeleri ile meşgul olacak şeyhin, seyrüsülûkünü tamamlamış olması, ${ }^{53}$ "cezbe" halinden kurtulup "temkîn" ve "sahv" hâline gelmesi lazımdır. Çünkü meczûb haldeki sâlik, henüz kalp ehlindendir. Onlar, bu makamda temkîn ve rüsûha erip kendileri için mârifet ve sahv hali gerçekleştiği zaman artık müritlere sohbet etmeye muktedir olurlar. ${ }^{54} \mathrm{Bu}$ yüzden şeyhten, müritlerini meczûb yapması beklenmez. Hatta meczûb haldeki şeyhin, tarîkat şeyhi olması caiz değildir. Zira tabi olunan şeyhin, kendisine intisâb eden müritlerin terbiyesi ile alakadar olması gerekir ki meczûb haldeki şeyhin, bu terbiyeyi yapması imkânsızdır. Aksine kemâle ermeye istidadı olan müritler, böyle şeyhlerin sohbetinde bulundukları zaman istidatlarını kaybedebilirler. İmâm-ı Rabbânî'ye göre mükemmel ve mükemmil olan bir şeyhin müritleri terbiye etmesi, tarlaya iyi bir tohum ekmeye, bu vasfa sahip olmayan şeyhlerin müritleri terbiye etmeye çalışması ise tarlaya kötü tohum ekmeye ${ }^{55}$ veya tıbbî bilgileri eksik olan bir doktorun hastaları tedavi etmesine benzer. ${ }^{56} \mathrm{Bu}$ yüzden müritlerin, şerîat ve hakîkat ilimlerinde kemâle ermemiş bir şeyhe intisap etmeleri doğru değildir.

İmâm-1 Rabbânî, başka bir mektubunda irşat vazifesi ile meşgul olacak şeyhin, fenâ ve bekâ makamlarını tamamlamış; "seyr ilellâh", "seyr fillâh", "seyr anillâh" ve "seyr fi'l-eşyâ" diye tabir edilen seyr makamlarını geçmiş olması gerektiğini söyler. Ona göre eğer bir şeyh, seyrüsülûkünü tamamlamadan önce cezbe ehlinden olmuş ve "murâd"

52 Serhendî, el-Mektûbât, 54. Mektup, 2/141.

53 Serhendî, el-Mektûbât, 292. Mektup, 1/515.

54 Serhendî, el-Mektûbât, 287. Mektup, 1/474.

55 Serhendî, el-Mektûbât, 287. Mektup, 1/475-476. (Ayrıca bk. Serhendî, el-Mektûbât, 292. Mektup, 1/515.)

56 Bk. Serhendî, el-Mektûbât, 61. Mektup, 1/109-110. 
382 | M. ÖZÇELIKK / İmâm-1 Rabbânî'nin el-Mektûbât İsimli Eseri Bağlamında Nakşibendiyye Şeyhlerinde Bulunması Gereken Vasıflar

konumunda olanların terbiye usulü ile terbiye görmüş ise "kibrît-i ahmer" gibi kıymetli olur. İmâm-1 Rabbânî'ye göre böyle şeyhin "konuşması devâ, nazarı şifâdır. Ölü kalplerin dirilmesi, onun şerefli teveccühüne ve azgın nefislerin tezkiyesi onun latîf iltifatına bağlıdır." 57

İmâm-1 Rabbânî, mânevî farkındalık anlamına gelen "sahv"1 esas alan bir tasavvufî anlayışa sahiptir. Ona göre mânevî sarhoşluk anlamina gelen "sekr", velâyet makamında olan sûfîlerin hâli; "sahv" ise nübüvvet makamı ile alâkası olan sûfîlerin hâlidir. Bütün peygamberlerin (a.s.) birbirlerine tebaiyet yolu ile sahv makamindan nasipleri vardır. Mesela Bâyezîd-i Bistâmî (ö. 234/848), sekri sahvına galip gelen sûfîlerdendir. $\mathrm{O}$, sekr halinin tesiriyle "Benim sancağım Muhammed'in sancağından daha yüksektedir." demiştir. İmâm-1 Rabbânî'ye göre o, bu sözle "sekr"e bakan velâyet sancağını, "sahv"a bakan nübüvvet sancağına tercih etmiştir. Buna benzer şekilde bazı mutasavvıflar da velâyetin Cenâb-1 Hakk'a, nübüvvetin ise halka yönelik olduğunu; dolayısıyla velâyetin, nübüvvetten daha faziletli olduğunu söylemişlerdir. Bazıları ise bir peygambere ait olan velâyet makâmının yine ona ait olan nübüvvet makamından daha üstün olduğunu ifade etmişlerdir. Buna benzer sözlerin tamamı yanlıştır. Çünkü nübüvvet makamindaki teveccüh, hem halka hem de Cenâb-1 Hakk'a doğrudur. Zira bu makamdaki zâtların bâtınları (kapleri) Hak Teâlâ ile zâhirleri ise halk iledir. Sadece halka teveccüh edenler ise Cenâb-1 Hak'tan yüz çevirip kaçan kimselerdir. "Peygamberlere (a.s.) gelince; onlar, bütün mevcûdâtın en faziletlileridir. En faziletli nimetler, onlara teslim edilmiştir. Velâyet, nübüvvetten bir cüzdür ve onun içine dürülmüş haldedir." Binaenaleyh nübüvvet makamı, aynı zamanda velâyet makamını da kapsamaktadır. Dolayısıyla nübüvvet, velâyetin her türünden daha faziletlidir. Velâyetin, nübüvvet içinde dürüldüğü gibi sekr de sahvin içine dürülmüştür. $O$ halde sahv hali de sekr hâlinden daha faziletlidir. Kaynağı nübüvvet olan şer'î ilimlerin tamamı, sahv halinden; şerîata muhalif olan şeylerin tamamı ise sekr halinden kaynaklanmıştır. Bütün bunlara rağmen sekr halinde bulunan kişiler, mazur görülmesi gereken kimselerdir. Taklit edilmeye ve sımsıkı takip

57 Serhendî, el-Mektûbât, 292. Mektup, 1/515. 
M. ÖZÇELIK / The Qualities that should have in the Naqshbandiyya Sheikhs in the Context of Imam Rabbani's Work Titled al-Maktubat | 383

edilmeye layık olan ilimler, sekr halinden kaynaklanan ilimler değil, sahv halinden kaynaklanan ilimlerdir." ${ }^{58}$

Ona göre sûfîler tarafından sarf edilmiş sözler, şayet şer'î hükümlere uygun değil ise kesinlikle onlara itibar edilmez; onlar hüccet kabul edilip taklit edilmez. Hüccet olmaya ve taklit edilmeye en layık olan Ehl-i Sünnet âlimlerinin sözleridir. Sûfîlerin sözleri, eğer bu âlimlerin sözlerine mutabakat gösterirse kabul edilir, muhalif olursa kabul edilmez. Bu düşünceden hareketle İmâm-1 Rabbânî, esasen istikâmet üzerinde olan sûfîlerin, hallerinde, amellerinde, ilimlerinde ve mârifetlerinde kesinlikle şerîatın sınırlarını aşmayacaklarını söyler. Ona göre istikâmet üzerinde olan gerçek sûfîler, şerîata muhalif olan şeylerin, hallerindeki mânevî hastalıktan kaynaklandığını ve sağlıklı olan hâlin, kesinlikle şerîata muhalif olamayacağını bilen kimselerdir. "Şerîata muhâlefet, zındıklık delili ve ilhâd alâmetidir." Bununla beraber eğer sûfî, içinde bulunduğu sekr hâlinin tesiriyle şerîata muhalif birtakım sözler sarf etmiş ise o ma'zûr görülür; ancak onun sözleri taklit edilmez; sarhoş kişinin sözlerinin, başka manalara hamledildiği gibi mânevî sarhoşluk içinde olan sekr halindeki kişinin sözleri de başka manalara hamledilir. ${ }^{59}$

İmâm-1 Rabbânî, şerîatın, bütün kemâlâtın anası ve bütün makamların aslı olduğunu, ${ }^{60}$ (tasavvufu temsil eden) tarîkat ve hakîkatin ise ihlâsı mükemmelleştirme konusunda şerîata yardım eden birer hizmetçi olduklarını, ancak bu gerçekten haberi olmayan kimselerin tarîkat ve hakîkati, şerîattan farklı şeyler olarak gördüklerini söyler. Ona göre bu kimseler, tarîkat ve hakîkatin kemâlâtını anlamak şöyle dursun, şerîatı anlamaktan bile aciz kalmışlardır. Bu acziyet, onların şerîatın kabuk, hakîkatin öz olduğu zannına kapılmalarına, (liyâkatsiz) sûfîler tarafından serdedilmiş şeriata muhalif saçma sapan sözlerle aldanmalarına ve birtakım süflî hâl ve makamlar sebebiyle fitneye

58 Serhendî, el-Mektûbât, 95. Mektup, 1/150. (Ayrica bk. a.mlf., el-Mektûbât, 71. Mektup, 2/190.

59 Serhendî, el-Mektûbât, 289. Mektup, 1/494-495. (İmâm-1 Rabbânî'nin "sekr" hakkındaki görüşleri hakkında geniş bilgi için bk. Ahmed Cahid Haksever, “Varoluşsal Kendinden Geçme ve Yansımaları: İmam Rabbânî'nin Şathiyye Anlayışı Örneği", Gazi Üniversitesi Çorum İlahiyat Fakültesi Dergisi 3/5 (2004) 105-124.)

60 Serhendî, el-Mektûbât, 46. Mektup, 2/124. 
384 | M. ÖZÇELIK / İmâm-1 Rabbânî'nin el-Mektûbât İsimli Eseri Bağlamında Nakşibendiyye Şeyhlerinde Bulunması Gereken Vasıflar

düşmelerine sebep olmuştur. ${ }^{61}$ Hâlbuki şerîat ile hakîkat, birbirinden farklı şeyler değil, aksine birbirinin aynı olan şeylerdir. Bir farkla ki şer'î bilgiler icmâlî, tasavvufî bilgiler ise tafsîlî bilgilerdir. Yine şer'î bilgiler, birtakım delillerle ortaya konmuş "istidlâlî" bilgiler, hakîkat ilmindeki (tasavvufî) bilgiler ise mânevî keşiflerle elde edilmiş "keşfî" bilgilerdir. ${ }^{62}$ Binaenaleyh (şerîatı temsil eden) "zâhir" ile (tarîkat ve hakîkati temsil eden) "bâtın" arasında kıl kadar bir ayrılık yoktur. Aksine bâtın, zâhiri tamamlayan ve onu mükemmelleştiren şeydir. Şayet tarîkat ve hakîkat yolunda ilerleyen bir müritten, şerîata muhalif birtakım şeyler zuhur edecek olursa bu, onun sekr halinde bulunduğunun bir göstergesidir. $\mathrm{O}$ mürit, sekr halinden sahv haline geçtiği anda ondaki şerîata muhalif hal ve ilimler tamamen ortadan kalkacaktır. ${ }^{63}$

\section{4. Şeyh, kendine intisâb edenlere nasıl muamelede}

\section{bulunması gerektiğini bilmelidir.}

İrşâd vazifesi ile meşgul olan şeyhin, tarikata girme talebiyle kendisine müracaat edilmesi durumunda birtakım şartlara riayet etmesi gerekmektedir. İmâm-1 Rabbânî'ye göre böyle bir taleple karşılaşan şeyh, bu talebin, kendisi için bir "istidrâc" olabileceğini ve bu yüzden hüsrâna uğrayabileceğini düşünmelidir. Ayrıca o, kendisine intisâb edenlerden dolayı sevinmemeli; Cenâb-1 Hakk'a tazarru ve iltica etmeli, o kişiye tarîkat talim etmenin, Cenâb-1 Hakk'ın rızasına uygun olduğuna yakînen inanıncaya kadar defalarca istihâre yapmalıdır. Çünkü Allah Teâlâ'nın izni olmaksızın O'nun kulları hakkında tasarrufta bulunmak ve (lâyık olmayan kimselerin) terbiyesi ile vakitleri zayi etmek caiz değildir. "Rablerinin izni ile insanları karanlıklardan nûra çıarman için..." (İbrâhim 14/1) âyet-i kerimesi, irşâdî faaliyetin, Cenâb-1 Hakk'ın izni ile yapılması gerektiğine işaret etmektedir. ${ }^{64}$

Şeyh, yaptı̆̆ı istihâreler neticesinde bir müride tarîkat talimi yapacağ1 zaman onun, geçmiş günahlarından tövbe etmesini sağlamalıdır. İmâm-1 Rabbânî'ye göre tövbe etmeyi emreden âyet-i

${ }^{61}$ Serhendî, el-Mektûbât, 40. Mektup, 1/79-80. (İmâm-1 Rabbânî'nin şerîat ve hakîkat hakkındaki yanlış telakkilere karşı yaptığı eleştiriler için bk. Yüksel Göztepe - Hamit Demir, “İmam Rabbânî’nin Sûfîlere Yönelttiği Bazı Tenkitler”, Tokat Gaziosmanpaşa Üniversitesi İlahiyat Fakültesi Dergisi 6/2 (2018), 307-308.)

62 Serhendî, el-Mektûbât, 84. Mektup, 1/142.

63 Serhendî, el-Mektûbât, 41. Mektup, 1/80.

64 Serhendî, el-Mektûbât, 211. Mektup, 1/274. 
M. ÖZÇELIK / The Qualities that should have in the Naqshbandiyya Sheikhs in the Context of Imam Rabbani's Work Titled al-Maktubat I 385

kerimelerden dolay $1^{65}$ günahlardan dolayı tövbe etmek zorunludur ve bu, her şahıs üzerine farz-1 ayındır. Peygamberler (a.s.) bile tövbeden müstağni kalmamışlardır. $O$ halde hiçbir insanın, kendisini tövbeden müstağni addetmesi düşünülemez. Günahlar, ya Allah Teâlâ'nın hukukuna ya da kulların hukukuna riayet etmemek şeklinde işlenir. Allah Teâlâ'ya karşı işlenmiş günahların tövbesi, işlenen günahlardan dolayı pişmanlık ve üzüntü duyup Cenâb-1 Hakk'a istiğfarda bulunmak ve O'ndan özür dilemek sûretiyle olur. Kulların hukukunu çiğnemek şeklinde işlenen günahların tövbesi ise işlenen zulümleri terk etmek, hakkı gasp edilen kişilere haklarını iade edip onlarla helalleşmek ve onlara iyilik yapıp hayır duada bulunmak şeklinde olur. Eğer hakkı gasp edilen kişi ölmüş ise istiğfar edilip (onun adına) iyilikte bulunulur ve haksızlıkla alınan mallar onun varislerine verilir. Şayet bu kimsenin varisi yoksa bu durumda onun niyetiyle fakirlere ve yoksullara sadaka verilir. İşte günahlarından dolayı bu şekilde tövbe ve istiğfarda bulunan kişi, aff-1 ilâhîye mazhar olur. Çünkü tövbe eden kimselerin affedileceği müjdelenmiştir. ${ }^{66} \mathrm{Bu}$ yüzden insan, 'Sonra tövbe ederim.' diyerek tövbeyi ihmal etmemelidir. Zira işini sonraya bırakanların helak olacağı haber verilmiştir. ${ }^{67}$

\section{5. Şeyh, şöhretten kaçınmalıdır.}

İsşâd vazifesi ile meşgul olan şeyh, devamlı surette tevâzu ile hareket etmeli, Cenab-1 Hakk'a ilticâ ve tazarruda bulunmalı, gönül kırıklığı içinde olmalı, kulluk vazifelerini itina ile yerine getirmeli, şerîatın sınırlarını muhafaza etmeli ve sünnet-i seniyyeye tam manasıyla tabi olmalıdır. Yine böyle bir şeyh, yaptığı her türlü hayırda niyetini tashih etmeli; iç âlemini ihlas ile donatmall, zahirini tertemiz yapmalı; kendi ayıplarını görmeli; günahların kendisini istila ettiğini müşahede etmeli ve her daim Allah Teâlâ'nın intikamından korkmalıdır. Yine o şeyh, çok da olsa yaptığı iyilikleri az görmeli; az da olsa işlediği günahları çok görmeli; şöhreti ve halkın hüsn-ü kabullerini kerih görmeli; Resûlullah'ın (s.a.v.) "Allah'ın koruduğu kişi müstesnâ, din ve

65 en-Nûr 24/31; et-Tahrîm 66/8; el-En'âm 6/120.

66 "Her kim, bir kötülük işler yahut kendine zulmeder sonra da Allâh'tan bağışlama dilerse Allâh'ı çok bağışlayıcı ve çok merhamet edici bulur." (en-Nisâ 4/110.)

67 Serhendî, el-Mektûbât, 66. Mektup, 2/166-167. 
386 | M. ÖZÇELIK / İmâm-1 Rabbânî'nin el-Mektûbât İsimli Eseri Bağlamında Nakşibendiyye Şeyhlerinde Bulunması Gereken Vasıflar

dünya konusunda parmakla gösterilmesi, kişiye şer olarak yeter."68 hadis-i şerifini aklından hiç çıkarmamalıdır. Yine böyle bir şeyh, sahih olsalar bile niyet ve amellerinden dolayı kendini töhmet altında tutmalı; vâkıalara mutâbık bile olsa hal ve vecdlerine odaklanıp onlara itimat etmemeli; Allah'ın, bu dini, yerine göre kâfir ve fâcir kimselerle bile güçlendireceğini düşünerek ${ }^{69}$ dîni destekleyip güçlendirmesini meziyet saymamalıdır. Yine o, tarîkat talebiyle kendisine gelen mürîdi, sanki bir aslan ve kaplan gibi görüp onun yüzünden hile ve istidrâca düşebileceğini düşünmeli; faraza bu durumdan dolayı kalbinde bir sevinç meydana gelmiş olsa bunu, şirk ve küfür olarak değerlendirmeli; bu sevinçten hiçbir eser kalmayıncaya kadar tövbe edip istiğfarda bulunmalıdır. Yine o şeyh, kendisine gelen müritlerin mal ve mülklerine asla tamah etmemelidir. Zira bu tamah, hem mürîdin irşadına mani olur hem de şeyhin harâb olmasına sebep olur. Zira dînin tamamı, sadece Allah Teâlâ'ya halis kılınmıştır.70 O'nun ulûhiyetinde hiçbir şekilde ortaklığa imkân yoktur. Bütün bunlara rağmen şeyh, şayet yukarıda sayılan şartlar konusunda bir hata yapmış ise Cenâb-1 Hakk'a tövbe ve istiğfar edip pişmanlık duymalı ve O'na iltica etmelidir. Ancak unutulmamalıdır ki şayet kalbe, alçak dünyanın muhabbetine dair bir zulmet çökmüş ise bu durum, son derece tehlikelidir. Zira Resûlullah (s.a.v.) "Dünya sevgisi, bütün hatâların başıdır." "71 buyurmuştur. Bu yüzden dünya ve dünyâ ehlinin sevgisi, öldürücü bir zehir, helak edici bir hastalık, büyük bir belâ ve umûmî bir derttir. ${ }^{72}$

\section{6. Şeyh, her türlü hal ve hareketlerinde müritlere örnek olacak sûrette olmalıdır.}

Müritlerin irşâdı ile meşgul olan şeyhin riayet etmesi gereken bir başka husus, müritlere örnek olacak nitelikte kendisine çeki düzen verip onların nefretine sebep olacak hal ve hareketlerden kaçınmaktır. Bu

68 Ebû 'Îsâ Muhammed b. 'Îsâ et-Tirmizî, el-Câmiu'l-kebîr, thk. Beşşâr Avvâd Ma'rûf (Beyrut: Dâru'l-Ğarbi'l-İslâmî, 1996), "Sıfatu-l Kıyâme”, 21 (No. 2453).

69 "Şüphesiz ki Allâh, bu dîni fâcir bir adam ile de güçlendirir." (Ebû Abdillâh Muhammed b. İsmâil el-Buhârî, Sahîhu'l-Buhârî (Beyrut: Dâru İbn Kesîr, 1423/2002), "Cihâd ve'ssiyer", 182 (No. 3062).

70 ez-Zümer 39/3.

71 Bk. İsmail b. Muhammed el-Cerrâhî el-Aclûnî, Keş̧ü'l-hafâ ve müzîlüll-ilbâs amme'ştehara mine'l-ahâdîsi alâ elsineti'n-nâs (Dimaşk: Mektebetü İlmi'l-Hadîs, 1422/2001), 1/344.

72 Serhendî, el-Mektûbât, 171. Mektup, 1/224-225. 
yüzden şeyhin, müritlerin nazarında (zâhiren ve bâtınen iyi bir konumda olabilmesi için) durumunu iyileştirmesi ve onların arasına haddinden fazla karışmaması lazımdır. İmâm-ı Rabbânî'ye göre bu durum, şeyhin müritler yanında hafif görülmesine dolayısıyla müritlerin ondan gereğince istifâde edememelerine sebep olur. Yine şeyh, şerîatın sınırlarını hakkıyla korumalı; mümkün mertebe ruhsatlarla amel etmemeye çalışmalıdır. Zira bu, sünnet-i seniyyeye uygun bir davranış olmadığı için Nakşibendiyye yoluna da aykırı bir davranıştır. ${ }^{73}$

Şeyh, müritler için numune bir şahsiyettir. Bu sebepten onun, müritlere örnek olmak için sergilediği hal ve hareketler, riya olarak değerlendirilmez. "Ârif kimselerin riyâsı, müritlerin ihlâsından daha hayırlıdır." denmesi bu yüzdendir. İmâm-1 Rabbânî, bu sözü izah sadedinde şöyle der: "Çünkü ârif kimselerin riyâsı, müritlerin kalplerini, Cenâb-1 Hakk'a (c.c) cezbetmek içindir. Bu yüzden (onların riyâsı), zorunlu olarak müritlerin ihlâsından daha faziletli olur. Aynen bunun gibi ârif kimselerin amelleri, amelleri yapma konusunda müritlerin onları taklit etmelerine bir sebep ve vasitadır. Şayet ârif kimseler, (alenen) amel işlememiş olsalar müritler amelden mahrum kalırlar. Binaenaleyh âriflerden riyâ sadır olması, kendilerine, müritlerin uymaları içindir. Bu riyâ, aslında ihlâsın ta kendisidir; hatta ondan daha faziletlidir. Çünkü (ihlâsın) faydası sadece sâhibi ile sınırlı iken bu (tür riyânın faydası) ise (başkalarına da) geçicidir." Ancak bu, 'Âriflerin bütün amelleri, müritlerin taklit etmelerine yöneliktir; kendilerinin bu amellere ihtiyacı yoktur." şeklinde anlaşılmamalıdır. Çünkü böyle bir düşünce, ilhâd ve zındıklıktan başka bir şey değildir. ${ }^{74}$

\section{7. Şeyh, töhmet altında kalacak hal ve hareketlerden kaçınmalıdır.}

İmâm-1 Rabbanî'nin tasavvuf anlayışında şerîata muhalif herhangi bir düşünce ve uygulamaya yer olmadığı gibi kişinin töhmet altında kalmasına ve insanların dinden ve din adamlarından nefret etmesine sebep olacak hiçbir düşünce ve uygulamaya da tahammül yoktur. $\mathrm{O}$, bu konuda son derece hassas olduğu gibi başkalarını aynı hassasiyete davet etmiştir. Bu bağlamda bulunduğu memlekette "şeyhülislâmlık"

73 Serhendî, el-Mektûbât, 227. Mektup, 1/305.

74 Serhendî, el-Mektûbât, 227. Mektup, 1/305. 
388 I M. ÖZÇELIK / İmâm-1 Rabbânî'nin el-Mektûbât İsimli Eseri Bağlamında Nakşibendiyye Şeyhlerinde Bulunması Gereken Vasıflar

makamina geçen Molla Tahir el-Lâhorî'ye bir mektup yazarak onu, hem tebrik etmiş hem de şöyle uyarmıştır:

“Bu nimetin şükrünü en güzel şekilde edâ edip halkın nefretine sebep olacak herhangi bir iş ortaya koymaktan son derece kaçınman gerekir. Çünkü bu, büyük bir vebaldir. Halkı nefrete sürüklemek, şeyhülislâmlık ve dâvet makâmı ile alâkası olmayan Melâmetî (meşrepteki) kişinin hâlidir. Bilakis Melâmeti (meşrepteki) kişi, şeyhülislâmlık makâmına karşı olan kişidir. Bu iki makamda, yani şeyhülislâmlık ve dâvet makamında hata işlemekten sakın! Yoksa sen, şeyhülislâmlık makamında Melâmetîlik mi yapmak istiyorsun?! Bu, büyük bir zulümdür. Sana düşen, müritlerin nazarında kendini iyileştirmendir. Bununla beraber irşâd talebinde bulunan kimselerin arasına karışıp onlarla ünsiyet kurmada ifrata kaçmaman lazımdır. Çünkü bu, hem şeyhin hafif görülmesine sebep olur hem de (şeyh ile mürit arasındaki) ifâde ve istifâde âdâbına aykırıdır. Şer'î sınırları muhafaza etmeye hakkıyla riayet etmen gerekir. Sakın ha! mümkün mertebe ruhsat ile amel etmeye cevaz verme. Çünkü bu davranış, bu üstün tarîkata ve sünnet-i seniyyeye mutâbaat davasına aykırıdır."75

\section{8. Şeyh, kadın müritleri hakkında şer'î ölçülere son derece riayet etmelidir.}

Şeyh, kendisine intisap etmek üzere bir kadın geldiğinde ona, tarîkat talimi yapabilir. Ancak bu durumda şeyh, gelen kadının mahrem ve nâmahrem oluşuna göre hareket etmelidir. Şayet gelen kadın, şeyhin mahreminden biri ise şeyhin, ona doğrudan tarîkat talimi yapmasında bir sakınca yoktur; ancak o kadın, şeyhin nâmahreminden biri ise şeyhin, ona ancak perde arkasından tarîkat talimi yapması uygun olur. ${ }^{76}$ Şeyhin, kadın müritlerle musâfaha ederek bîatta bulunması doğru değildir. Zira Resûlullah (s.a.v.), kadın Müslümanlarla sadece söz ile bîatta bulunmuş, onlarla musâfaha etmemiştir. ${ }^{77} \mathrm{O}$ halde (Resûlullah'in

75 Serhendî, el-Mektûbât, 227. Mektup, 1/305.

76 Serhendî, el-Mektûbât, 256. Mektup, 1/352.

77 "Ben, kadınlar ile musâfaha etmem..." Bk. Ebû Abdillah Muhammed b. Yezîd elKazvînî ibn Mace, Sünen, thk. Muhammed Fuad Abdülbaki (b.y.: Dâru İhyâi'lKütübi'l-Arabiyye, ts.), "Cihâd", 43 (No: 2874-2875). Bu konuda geniş bilgi için bk. M. Ali Kapar, "Hz. Peygamber Döneminde Bey'at", Necmettin Erbakan Üniversitesi İlahiyat Fakültesi Dergisi 5/5 (Haziran 1994), 82; Dilaver Selvi, “Biat Sünnetinin Tasavvufta İhyası", Uluslararası İslam Araştırmaları Dergisi (IHHYA) 1/1 (2015), 8-9. 
M. ÖZÇELIK / The Qualities that should have in the Naqshbandiyya Sheikhs in the Context of Imam Rabbani's Work Titled al-Maktubat I 389

(s.a.v.) vârisi konumunda bulunan) şeyh de aynı şekilde hareket etmelidir. ${ }^{78}$

\section{Sonuç}

Bu makalede dînî ve tasavvufî sahada gerçekleştirmiş olduğu tecdîd hareketi sayesinde "ikinci bin yılın yenileyicisi" (Müceddid-i Elf-i Sânî) lakabına layık görülmüş olan İmâm-1 Rabbânî Ahmed Fâruk esSerhendî̀nin, tasavvufî terbiyenin muallimi konumunda olan "şeyh" unsuruna bakışı ortaya konmaya çalışılmıştır. Kanaatimizce onun tasavvufî anlayışı ve ortaya koymuş olduğu şeyhlik vasıfları, genel olarak İslâm’ın talim ve tedrisi ile meşgul olan bütün ilim câmiasına, özel olarak da tasavvufla alakadar olan Müslümanlara önemli mesajlar vermektedir. Bu mesajları, kısaca şöyle özetlemek mümkündür:

Tasavvuf, tarîkat ve hakîkat, şeriattan farklı şeyler değil, aynı şeyin farklı bakış açılardan ifâde edilmiş halleridir. Bu itibarla şerîata muhalif olan hiçbir tasavvufî düşünce ve uygulama, makbul olmadiğ1 gibi son derece tehlikelidir. Tarîkat ile şerîat, birbirine muhâlif şeyler olmadığı için her ikisinin gayesi de aynıdır. Bununla beraber tarîkat, şerîatın hizmetçisidir.

Hakîkî şeyh, hırka ve külah giymek gibi zâhirî alametleri üzerinde taşıyan kişi değil, Cenâb-ı Hakk'a vâsıl olmanın yollarını bilip bu konuda müritlerine yardım eden zâttır. Böyle şeyhler, Resûlullah'ın (s.a.v.) hakîkî vârisleridir. Ona varis olan şeyhin, birtakım vasıflara sahip olması gerekmektedir. Şöyle ki;

Şeyh, öncelikle Resûlullâh'in (s.a.v.) ilmî ve irşâdî mirasından nasipdar olmalı, yani ahkâm ve esrâr ilimlerinden müteşekkil olan şer'î ilimlerden haberdar olmalıdır. Şer'î ahkâma dair ilimler, bütün kemâlâtın anası ve bütün makamların aslıdır. Bu ilimlerinden yoksun olan birinin, tasavvufî hal ve makamlarla ilgili "esrâr" ilmini öğrenmesi, hiçbir mânâ ifade etmez. Esasen şer'î ilimlerle desteklenmeyen bilgilerin hakîkî tasavvufla alakası yoktur. Binaenaleyh irşâdî faaliyette bulunacak olan şeyh, sadece tasavvufî bilgiler ile iktifa etmemeli, şer'î ilimlerle tasavvufî ilimleri mezcetmelidir.

Şeyh, her hususta Resûlüllâh'a (s.a.v.) sünnet-i seniyyesine mutâbaat içinde olmalıdır. Bu mutâbaatın yedi derecesi vardır. Hakîkî şeyhin, en azından mutâbaatın dördüncü derecesinde bulunması

78 Serhendî, el-Mektûbât, 41. Mektup, 3/82. 
390 I M. ÖZÇELIK / İmâm-1 Rabbânî'nin el-Mektûbât İsimli Eseri Bağlamında Nakşibendiyye Şeyhlerinde Bulunması Gereken Vasıflar

gerekmektedir. Şerîatın hakikatine vâkıf olmaktan ibaret olan bu dereceye, "nefs-i mutmainne" makamında kemâle ermekle erişilir. Bu dereceye vâsıl olmayan şeyhin, başkalarını irşâd etmesi mümkün değildir.

Başkalarının irşâdını üstlenecek olan şeyh, bir şeyh-i kâmil-i mükemmilin gözetiminde terbiye görüp seyrüsülûkünü tamamlamış olmalıdır. Seyrüsülûkünü tamamlamayan kimseler, bazen cezbe halinde olup şerîatın zâhirine muhalif birtakım sözler sarf edebilirler. Halbuki hakîkî şeyhten, şer'î hükümlere muhâlif hiçbir söz, düşünce ve hareket sâdır olmaz. Şayet şeyh olduğunu iddia eden birinden bu tür şeyler sadır olmuş ise bu, o kişinin irşâda ehil bir şeyh olmadığının göstergesidir. Böyle kimselerin sözlerine asla itibar edilmez.

İşâdî faaliyette bulunan şeyh, kendisine intisâb eden müritlere nasıl muamelede bulunması gerektiğini bilmelidir. O, öncelikle yaptığı irşâdî faaliyetlerin, Cenâb-1 Hakk'ın izniyle olduğunu bilmeli; kendisine intisâb eden müritleri, övünç, şöhret ve menfaat vâsıtası yapmamalı; her daim ihlaslı ve alçak gönüllü olmalı; müritlerini irşâd etmede muvaffak olup bu konuda fitneye düşmemek için sürekli Cenâb-1 Hakk'a yalvarıp yakarmalıdır.

Yine şeyh, Resûlüllâh'ın (s.a.v.) irşâd makamına vâris olduğunun bilinciyle her türlü hal ve hareketlerinde sünnet-i seniyyeye uygun davranıp müritlerine örnek olmalı; temsil ettiği makamı küçük düşürecek hiçbir hal ve hareket sergilememeli ve kadın müritleri hakkında mahremiyet kurallarına hassasiyetle riayet etmelidir. $\mathrm{Bu}$ hususlara riayet etmeyen biri, insanları irşâd etmek yerine onların irşâdına mani olacak, temsil ettiği makâmın insanlar nezdinde küçük görülmesine sebep olacaktır.

Hulasa olarak söylemek gerekirse; insanları irşâd etme konusunda Resûlüllâh'ın (s.a.v.) varisi konumunda bulunan şeyhler, sıradan kimseler değildir. Onların, bu vazifeyi hakkıyla îfa edebilmeleri için birtakım vasıfları taşımaları gerekmektedir. Bu vasıfları taşıyan şeyhler, kendisine intisâb edenlerin mânevî gelişimlerine katkı sağlarlar. Bu vasıflardan yoksun olan sözde şeyhler ise insanları mânen kemâle erdirmek şöyle dursun, onları, mevcut hallerinden daha aşağıya düşürürler. Geçmişte ve günümüzde ortaya çıkan kifayetsiz ve sahte şeyhler, İmâm-1 Rabbânî'nin bu konudaki endişelerini haklı çıkarmıştır. Zira şeyhlik vasıflarından hiçbirini üzerinde taşımayan ve hakîkî 
M. ÖZÇELIK / The Qualities that should have in the Naqshbandiyya Sheikhs in the Context of Imam Rabbani's Work Titled al-Maktubat I 391

tasavvuftan habersiz olan birtakım liyâkatsiz şahsiyetler, şeyhlik iddiasıyla ortaya çıkmakta, sergiledikleri bazı gayr-i meşrû hal ve hareketler ile İslâm'ın neşrinde ve insanların irşâdında büyük emekleri geçen hakîkî şeyhlere dil uzatılmasına, onlara düşmanlık yapılmasına daha da kötüsü, bütün din adamlarına karşı menfî tavır takınılmasına sebep olmaktadırlar. Bu itibarla hakîkî şeyh ile sözde şeyhi birbirinden ayırt edip bu konuda fitneye düşmekten kurtulmak için her Müslümanın, İmâm-1 Rabbânî gibi hakîkî mutasavvıflar tarafından belirlenmiş olan hakîkî şeyhlik vasıflarını bilmesi gerekmektedir.

\section{Kaynakça}

Aclûnî, İsmail b. Muhammed el-Cerrâhî. Keșfü'l-hafâ ve müzîlü'l-ilbâs amme'ştehara mine'l-ahâdîsi alâ elsineti'n-nâs. 2 Cilt. Dimaşk: Mektebetü İlmi'1-Hadîs, 1422/2001.

Algar, Hamit. "İmâm-1 Rabbânî". Türkiye Diyanet Vakfi İslâm Ansiklopedisi. 22/194-199. İstanbul: TDV Yayınları, 2000.

Algar, Hamit. "Mektûbât". Türkiye Diyanet Vakfi İslâm Ansiklopedisi. 29/11-12. Ankara: TDV Yayınları, 2004.

Bilgin, İbrahim Ethem. Devrimci Sûfi Hareketleri ve İmam-ı Rabbânî. İstanbul: Bayrak Yayımcılık, 1989.

Buhârî, Ebû Abdillâh Muhammed b. İsmâil. Sahîhu'l-Buhârî. Beyrut: Dâru İbn Kesîr, 1423/2002.

Cebecioğlu, Ethem. "İmâm-1 Rabbani ve Mektubâtı". Ankara Üniversitesi Ilahiyat Fakültesi Dergisi 35/1 (1996), 193-241.

Cebecioğlu, Ethem. "Mektûbât". Tasavouf Klasikleri. ed. Ethem Cebecioğlu. 449-470. İstanbul: Erkam Matbaacılık, 2010.

Cürcânî, Seyyid Şerîf. Ta'rifât. nşr. Abdurrahman Umeyra. Beyrut: Âlemü'l-Kütüb, 1987.

Gazâlî, Ebû Hâmid Muhammed. İhyâü Ulûmi'd-Dîn. thk. Ali Muhammed Mustafa - Saîd el-Mehâsinî. 5 Cilt. Dimaşk: Dâru'1Feyhâ, 1431/2010.

Göztepe, Yüksel - Demir, Hamit. “İmam Rabbânî’nin Sûfîlere Yönelttiği

Bazı Tenkitler". Tokat Gaziosmanpaşa Üniversitesi İlahiyat Fakültesi Dergisi 6/2 (2018), 297-322.

Haksever, Ahmed Cahid. "Varoluşsal Kendinden Geçme ve Yansımaları: İmam Rabbânî'nin Şathiyye Anlayışı Örneği". Gazi Üniversitesi Çorum İlahiyat Fakültesi Dergisi 3/5 (2004), 103-126. 
392 I M. ÖZÇELIK / İmâm-1 Rabbânî'nin el-Mektûbât İsimli Eseri Bağlamında Nakşibendiyye Şeyhlerinde Bulunması Gereken Vasıflar

Hânî, Abdülmecîd b. Muhammed. el-Kevâkibü'd-dürriyye ale'lhadâikı'lverdiyye fì ecillâi's-sâdâti'n-Nakşibendiyye. tsh. Muhammed Halid el-Harse. Dımaşk: Dâru'l-Beyrûtî, 1996.

Hasenî, Şerîf Abdülhay b. Fahruddîn. Nüzhetü'l-havâtır ve behcetü'lmesâmi've'n-nevâzır. 8 Cilt. Beyrut: Dâru İbn-i Hazm, 1420/1999.

İbn Mâce, Ebû Abdillah Muhammed b. Yezîd el-Kazvînî. Sünen. thk. Muhammed Fuad Abdülbaki. 2 Cilt. b.y.: Dâru İhyâi'l-Kütübi'lArabiyye, ts.

İmam-1 Rabbânî, Ahmed Fâruk es-Serhendî. el-Mektûbât. 3 Cilt. İstanbul: Fazilet Neşriyat, 2017.

Kapar, M. Ali. “Hz. Peygamber Döneminde Bey'at". Necmettin Erbakan Üniversitesi Illahiyat Fakültesi Dergisi 5/5 (Haziran 1994), 75-82.

Kartal, Abdullah. "İmâm-1 Rabbânî'nin Vahdet-i Vücûd Eleştirisi ve Tarihsel Arka Planı". Uludă̆ Üniversitesi İlahiyat Fakültesi Dergisi 14/2 (Haziran 2005), 59-80.

Kâşânî, Abdürrezzak. Tasavvuf Sözlü̆ğü Letâifü̈l-a 'lâm fi işârâti ehli'lilhâm. çev. Ekrem Demirli. İstanbul: İz Yayıncılık, 2004.

Kılıç, Cevdet. “Günümüz Tasavvuf Tartışmalarına İmâm-1 Rabbânî'den Çözümler". Akademiar Dergisi 2 (Haziran 2017), 55-98.

Kılıç, Rüya. "Nakşibendi Geleneğinde İbnü'l-Arabi: Destek mi Muhalefet mi?". Hacettepe Üniversitesi Türkiyat Araştırmaları (HÜTAD) 6 (Haziran 2007), 43-60.

Kuşeyrî, Abdülkerîm. er-Risâletü'l-Kuşeyriyye. tsh. Hânî el-Hâc. Kâhire: el-Mektebetü't-Tevfîkıyye, ts.

Münâvî, Muhammed Abdu'r-Raûf. Feydu'l-kadîr. 6 Cilt. Misır: elMektebetü't-Ticâriyyeti'l-Kübrâ, 1356.

Nedvî, Ebü'l-Hasan. İslam Önderleri Tarihi. çev. Yusuf Karaca. 8 Cilt. İstanbul: Kayıhan Yayınları, 1992.

Nedvî, Ebü'l-Hasan. ed-Da'vetü'l-İslâmiyye fi'l-Hind ve Tatavvurâtühâ. Lucknow: el-Mecmeu'l-İslâmî el-İlmî, 3. Basım, 1406-1986.

Nedvî, Ebü'l-Hasan. el-İmâm es-Sirhindî Hayâtühû ve A'mâlühû. Beyrut: Dârul'1-Kalem, 1414/1994.

Nedvî, Mes'ûd. Târihu'd-Da'veti'l-İslâmiyye fi'l-Hind. b.y.: Dâru'lArabiyye, 1366/1947.

Özgen, Mustafa. İmâm-ı Rabbânî Uluhiyyet ve Nübüvvet Anlayışı. Konya: Tablet Yayınları, 2007. 
M. ÖZÇELIKK / The Qualities that should have in the Naqshbandiyya Sheikhs in the Context of Imam Rabbani's Work Titled al-Maktubat I 393

Özgen, Mustafa. İmâm-ı Rabbân̂̀'de Ehl-i Sünnet Kimliği. Konya: Palet Yayınları, 2013.

Selvi, Dilaver. "Biat Sünnetinin Tasavvufta İhyası". Uluslararası İslam Araştırmaları Dergisi (IHYYA) 1/1 (2015), 1-28.

Schimmel, Annemarie. İslamın Mistik Boyutları. çev. Ergun Kocabıyık. İstanbul: Kabalcı Yayınevi, 2004.

Sühreverdî, Şehâbüddîn Ebû Hafs Ömer b. Muhammed. Âvârifü'l-maârif. Beyrut: Dâru'1-Kütübü'1-İlmiyye, 1999.

Şarkpûrî, Muhammed Halim. Müceddi-i Elf-i Sânî İmâm Rabbânî. çev. Ali Genceli. Konya: İslâmi Neşriyat Yayınevi, 1978.

Tirmizî, Ebû 'Îsâ Muhammed b. 'Îsâ. el-Câmiu'l-kebîr. thk. Beşşâr Avvâd Ma'rûf. 6 Cilt. Beyrut: Dâru'l-Ğarbi'l-İslâmî, 1996.

Tosun, Necdet. İmâm-ı Rabbânî Ahmed Sirhindî Hayatı, Eserleri, Tasavoufî Görüşleri. İstanbul: İnsan Yayınları, 3. Basım, 2016.

Tosun, Necdet. “İmam Rabbânî'ye Göre Vahdet-i Vücud-Vahdet-i Şühûd". Tasavvuf: İlmi ve Akademik Araştırmalar Dergisi (İbn Arabi Özel Sayıst-2) 23 (2009), 181-192.

Uludağ, Süleyman. Tasavouf Terimleri Sözlüğ̈̈. İstanbul: Kabalc1 Yayınları, 2005.

Yaran, Rahmi. "Bid'at". Türkiye Diyanet Vakfı İslâm Ansiklopedisi. 6/129131. İstanbul: TDV Yayınları, 1992. 